\title{
Anti-climacterium effects of pomegranate concentrated solutions in ovariectomized ddY mice
}

\author{
SU JIN KANG ${ }^{1,2^{*}}$, BEOM RAK CHOI $^{3 *}$, SEUNG HEE KIM $^{3}$, HAE YEON YI $^{3}$, HYE RIM PARK $^{3}$, \\ CHANG HYUN SONG ${ }^{1,4}$, SAE KWANG KU ${ }^{1,4}$ and YOUNG JOON LEE ${ }^{1,2}$
}

\begin{abstract}
${ }^{1}$ The Medical Research Center for Globalization of Herbal Medicine, Daegu Haany University; ${ }^{2}$ Department of Preventive Medicine, College of Korean Medicine, Daegu Haany University, Gyeongsan, Gyeongsangbuk-Do 38610; ${ }^{3}$ Research Institute, Health-Love Co., Ltd., Anyang, Kyunggi-Do 13946; ${ }^{4}$ Department of Histology and Anatomy, College of Korean Medicine,

Daegu Haany University, Gyeongsan, Gyeongsangbuk-Do 38610, Republic of Korea
\end{abstract}

Received October 11, 2015; Accepted October 5, 2016

DOI: $10.3892 / \mathrm{etm} .2017 .4109$

\begin{abstract}
In the present study, the complex anti-climacterium potential of standardized pomegranate concentrated solution (PCS) was investigated using bilateral ovariectomy (OVX) female ddY mice. Changes in body weight and gain during experimental periods, food consumption, serum estradiol levels, total body and abdominal fat densities, abdominal fat pads, and uterus weights were observed, along with the histopathology of abdominal fat pads and uterus for anti-obesity and estrogenic effects. In addition, liver weights, serum aspartate aminotransferase (AST), alanine aminotransferase (ALT) levels, and histopathological inspections were performed to explore the hepato-protective effects. Serum total cholesterol (TC), low density lipoprotein (LDL), high density lipoprotein, and triglyceride (TG) levels were monitored for hypolipidemic effects with total body and femur mean bone mineral density (BMD), right femur wet, dry and ash weights, strength, serum osteocalcin, bone-specific alkaline phosphatase (bALP) contents, and histological and histomorphometrical analyses for anti-osteoporosis activity. As a result of OVX, notable increases in body weight and gains, food consumption, abdominal fat mass densities, weights of abdominal fat pads
\end{abstract}

Correspondence to: Professor Sae Kwang Ku, Department of Histology and Anatomy, College of Korean Medicine, Daegu Haany University, 1 Haanydae-ro, Gyeongsan, Gyeongbuk-Do 38610, Republic of Korea

E-mail: gucci200@hanmail.net

Professor Young Joon Lee, Department of Preventive Medicine, College of Korean Medicine, Daegu Haany University, 1 Haanydae-ro, Gyeongsan, Gyeongbuk-Do 38610, Republic of Korea

E-mail: gksxntk@dhu.ac.kr

*Contributed equally

Key words: pomegranate concentrated solution, anti-climacterium, ovariectomy, ddY mice deposited in the abdominal cavity, and serum AST, ALT, TC, LDL, TG, and osteocalcin levels were observed, along with decreases in the uterus, liver, and femur weights, mean total body and femur BMD, femur strength, serum bALP, and estradiol levels. In addition, marked hypertrophic alterations in adipocytes located in the deposited abdominal fat pads, liver steatosis, uterine disused atrophic changes, and decreases in bone mass and structures of the femur were also observed in OVX control mice with significant increases in bone resorption markers based on histopathological and histomorphometrical analysis. However, these estrogen-deficient climacterium symptoms were significantly $(\mathrm{P}<0.05$ or $\mathrm{P}<0.01)$ inhibited after 84 days of continuous treatment with estradiol and PCS $(1,2$ and $4 \mathrm{ml} / \mathrm{kg})$, respectively. The present results suggested that PCS was able to effectively inhibit or refine the climacterium symptoms, including obesity, hyperlipidemia, hepatic steatosis, and osteoporosis, induced by OVX in ddY mice.

\section{Introduction}

Hormone levels may cause changes in sexual function in women as a result of aging and during the climacteric period; as such, women aged 40-65 years experience changes in hormone levels and gradually lose their reproductive capacity (1). This period is associated with the loss of activity of the ovarian follicles, with consequent estrogen deficiency (2).

Approximately $70 \%$ of women experience symptoms during the climacteric period. In general, these symptoms are responsible for estrogen deprivation. The most common symptoms are vasomotor symptoms, night sweats, cognitive impairment, insomnia, depression, irritability, fatigue, psychological symptoms, and increased risk for osteoporosis and cardiovascular disease $(1,3)$. In addition, vaginal dryness, dyspareunia, and urinary urgency, which are related to urogenital atrophy, may negatively affect the sex life and quality of life of postmenopausal women $(2,4)$. Previous studies have suggested that the potential risk of metabolic diseases, including obesity, heart disease, diabetes and hypertension, are increased in the postmenopausal state $(5,6)$. These metabolic diseases are attributed to estrogen deficiency. Obesity has secondary effects due to the orexigenic 
actions of estrogen deficiency $(7,8)$. The association between menopause and cardiovascular disease has been demonstrated in a previous epidemiological study $(9,10)$. Estrogen deficiency is associated with an atherogenic lipid profile characterized by high-density lipoprotein (HDL) cholesterol, low-density lipoprotein (LDL) cholesterol, triglyceride levels (11), central adiposity (12), increased diastolic pressure (13) and increased insulin resistance (14).

Hormone therapy can be used to reduce the risk of ovarian failure and improve women's health; however, this treatment may cause serious problems over extended periods of time. Long-term treatment results in an increase in cardiovascular events and breast cancer (15-17); thus, alternative therapies, such as the use of phytoestrogens (PEs) to relieve menopausal symptoms, have gained attention $(1,18,19)$.

Purified phytohormones, such as genistein which is abundant in soybean, exhibit improved activity in the body and enhanced bioavailability (18). PEs is able to bind to estrogen receptors, due to the presence of a phenolic ring, and function like estrogens (18-20). Coumestrol and the isoflavonoids genistein, daidzein, and their plant precursors, are predominantly found in soybeans and clover (21). Isoflavones, particularly those derived from plants, have various biological activities, are able to improve the metabolic symptoms (22) and exhibit bone-protective effects (23) during menopause. To date, pomegranate extract has been shown to be a selective estrogen receptor modulator (24).

Pomegranate (Punica granatum L.) is consumed as a fresh fruit, beverage, dietary supplement, and is a herbal medicine ingredients (25). Pomegranate juice and pomegranate polyphenol extracts have been demonstrated to prevent various types of cancer, cardiovascular disease, diabetes, Alzheimer's, arthritis, colitis, and several other diseases (26-28). Polyphenols, which is one of the active substances of pomegranate, are present in numerous parts of pomegranate fruits (29). It has been shown that pomegranate contains species of flavonoids and anthocyanidins in their seed oil and juice $(30,31)$.

The anti-climacterium effective optimal dosages of standardized pomegranate concentrated solution (PCS) remain unclear. Therefore, the complex anti-climacterium potential of PCS was examined with optimal dose ranges using female ddY mice subjected to bilateral ovariectomy (OVX). Estrogen-deficient animals induced by OVX were used as a climacterium model as several climacterium symptoms are clearly induced by OVX within 4 to 6 weeks after the surgery. OVX-treated ddY mice have also been used to investigate the mechanisms underlying menopause-related complications in humans as these complications share various similarities with postmenopausal climacterium symptoms (32-34). This rodent model exhibits symptoms that resemble those of women with postmenopausal climacterium symptoms, including cardiovascular diseases, obesity, hyperlipidemia, osteoporosis, organ steatosis and mental disorders (35-38). In the present study, anti-climacteric effects were evaluated and separated into five categories: i) estrogenic effects; ii) anti-obese effects; iii) hypolipidemic effects; iv) hepatoprotective effects against liver steatosis; and v) anti-osteoporotic effects. The results suggest that PCS treatment suppressed OVX-induced obesity, hyperlipidemia, hepatic steatosis and osteoporosis in $\mathrm{ddY}$ mice.

\section{Materials and methods}

Animals and husbandry. A total of 48 virgin female specific pathogen-free outbred-mice (Kwl:ddY; age, 6 weeks; weight, 24-26 g; Kiwa Laboratory Animal, Wakayama, Japan), were used for the present study following acclimatization for 16 days. Animals were allocated four per polycarbonate cage in a temperature $\left(20-25^{\circ} \mathrm{C}\right)$ and humidity $(45-55 \%)$ controlled room with a 12-h light/dark cycle. Feed (Samyang, Seoul, Korea) and water were supplied free to access. A total of 28 days after OVX surgery, eight mice per group were selected based on body weight. All laboratory animals were treated according to the national regulations on the usage and welfare of animals and approved by the Institutional Animal Care and Use Committee of Daegu Haany University (Gyeongsan, Korea) prior to the experiments (approval no. DHU2014-0210). Experiments on osteoporosis were conducted in accordance with the US Food and Drug Administration 'Guidelines for Preclinical Evaluation of Agents Used in The Prevention or Treatment Postmenopausal Osteoporosis' (39).

Preparation and administration of test substances. Compound (17 $\beta$ )-estra-1,3,5(10)-triene-3,17-diol (17 $\beta$-estradiol) was purchased from Sigma-Aldrich (Merck Millipore, Darmstadt, Germany). Standardized PCS were supplied by Health Love Ltd. (Anyang, Korea) as deep reddish viscous solutions. The energy of PCS was 244.69 Kcal/100 g, and PCS contained $2.31 \mathrm{mg} / \mathrm{g}$ ellagic acid, $58.86 \%$ carbohydrate, $1.21 \%$ total protein, $0.49 \%$ fat, $27.97 \%$ water, $1.47 \%$ ash, and $28.03 \mathrm{mg} / 100 \mathrm{~g}$ sodium. PCS $(0.67 \mathrm{ml})$ was diluted as clear reddish solutions in $1 \mathrm{ml}$ distilled water. Subsequently, 1, 2 and $4 \mathrm{ml} / \mathrm{kg}$ (according to body weights) of PCS were orally administered once a day for 84 days from 28 days after OVX in a volume of $10 \mathrm{ml} / \mathrm{kg}(\mathrm{v} / \mathrm{v})$, diluted with distilled water, using a gastric gavage attached to a $1 \mathrm{ml}$ syringe. In OVX and sham control mice, distilled water was used as a vehicle. In addition, 17 $\beta$-estradiol (Sigma-Aldrich; Merck Millipore) was subcutaneously administered into the dorsal back skins at a volume of $0.2 \mathrm{ml} /$ mouse $(0.03 \mu \mathrm{g} / \mathrm{head} /$ day $)$, according to previously established methods (40-42).

Menopause induction via bilateral OVX. Mice were anesthetized with a $25 \mathrm{mg} / \mathrm{kg}$ intraperitoneal injection of Zoletile mixture (Zoletile 50 ${ }^{\mathrm{TM}}$; Virbac Lab., Carros Cedex, France) and maintained with $1-1.5 \%$ isoflurane (Hana Pharm. Co., Hwasung, Korea) in a mixture of $70 \% \mathrm{~N}_{2} \mathrm{O}$ and $28.5 \%$ $\mathrm{O}_{2}$. The surgical protocol was performed according to established methods $(35,37,38)$. The OVX treatment group $(n=8)$ underwent open surgery involving bilateral OVX via a midline incision of linea alba. Following surgery, the incision was closed in two layers. Muscular layers were sutured independently from the peripheral tissues using dissolvable 3-0 vicryl sutures and the skin was closed by continuous sutures using silk (3-0). The second group of mice $(n=8)$ underwent sham surgery, in which a similar incision in the linea alba was made but bilateral OVX was not performed.

Body weight measurements. Alterations in body weight were measured once a week from OVX, one day before administration, and at sacrifice (at 84 days after the first administration, the 
mice were anesthetized with $50 \mathrm{mg} / \mathrm{kg}$ tiletamine/zolazepam and dissected) using an automatic electronic balance (Precisa Gravimetrics, Inc., Dietikon, Switzerland). At OVX, initiation of administration, and at termination, all experimental animals were fasted overnight for $18 \mathrm{~h}$ (water was provided) to reduce the differences from feeding. In addition, body weight gains were calculated as follows: OVX recovery/induced periods $(28$ days $)=$ [body weight at initial test substance treatment - body weight on the day of OVX surgery]; and after administration (84 days) $=$ [body weight at sacrifice - body weight at initial test substance treatment].

Food consumption measurements. All mice were allocated into individual cages and received $150 \mathrm{~g}$ diets. The quantity of diets supplied were measured at $24 \mathrm{~h}$ after feed supply using an automatic electronic balance (Precisa Gravimetrics, Inc) and were considered to indicate the daily food consumption of individual mice ( $\mathrm{g} / 24 \mathrm{~h} /$ mouse). These measurements were conducted six times: 1, 3, 7, 28, 56 and 83 days after the first administration.

Measurement of bone mineral density (BMD) and body fat density. The mean BMD of the total body and right femur were detected once using live dual-energy X-ray absorptionmetry (InAlyzer; Medikors, Seungnam, Korea) at the end of 84 days of continuous treatment with the test substances. The mean fat densities of the body and abdominal cavity of each mouse were recorded.

Organ weight measurements. Following sacrifice, the abdominal fat pads deposited in the abdominal cavity, total liver, and uterus (including vagina) were collected after removing the surrounding connective tissues, muscles, and any debris. The weights of organs were measured in grams to determine the absolute wet-weights. To reduce individual body weight differences, the relative weights (\% of body weight) were calculated using body weight at sacrifice and absolute wet-weight, as follows: Relative organ weights (\% of body weight $)=[$ (absolute abdominal fat pad, uterus or liver weights/body weight at sacrifice) $x$ 100].

Bone weight measurements. Following 84 days of continuous treatment from 28 days after bilateral OVX surgery, the right sides of the femurs were harvested after removing the surrounding connective tissues, muscles, and any debris. Bone weight was measured in grams to determine the absolute wet-weights, and they were dried at $120^{\circ} \mathrm{C}$ for $8 \mathrm{~h}$ in a high temperature dry oven (LDO-080N; Daihan Labtech Co., Seoul, Korea) for measurements of dry bone weights. Subsequently, dried bones were carbonized at $800^{\circ} \mathrm{C}$ for $6 \mathrm{~h}$ in a furnace (LEF-1055-1; Daihan Labtech Co.) to measure ash absolute weights. To reduce the individual body weight differences, the relative weight (\%) was calculated based on the body weight at sacrifice and absolute wet/dry/ash weight, as follows: Relative bone weights (\% of body weight $)=[($ absolute bone weight/body weight at sacrifice) $\mathrm{x} 100]$.

Measurement of bone strengths. Bone strength was detected as the failure load (FL). We used FL calculated using a test machine (SV-H1000; Japan Instrumentation System, Co., Nara,
Japan). The FL of the mid-shaft regions of the right femurs was detected using a three-point bending test to failure using a computerized testing machine (SV-H1000; Japan Instrumentation System Co., Yokohama, Japan) as N (Newton), according to the manufacturer's instructions.

Blood collection. For serum biochemical analysis, $\sim 1 \mathrm{ml}$ whole blood was collected from the vena cava at sacrifice and was separated from the serum by centrifugation at 21,000 $\mathrm{xg}$ for $10 \mathrm{~min}$ at $4^{\circ} \mathrm{C}$ using a clotting activated serum tube. All serum samples were frozen at $-150^{\circ} \mathrm{C}$ until they were assayed.

Serum biochemistry. Serum aminotransferase (AST), alanine aminotransferase (ALT), total cholesterol (TC), LDL, and triglyceride (TG) levels were detected using an automated blood analyzer (Hemagen Analyst; Hemagen Diagnostics, Columbia, MD, USA), and HDL levels were measured using another automated blood analyzer (AU400; Olympus Corp., Tokyo, Japan). In addition, serum osteocalcin levels ( $\mathrm{ng} / \mathrm{ml})$ were detected using a Mouse Osteocalcin ELISA kit (Immutopics, San Clemente, CA, USA), and serum bALP levels (U/l) were detected using a Mouse bALP ELISA kit (Quidel Corp., San Diego, CA, USA), with an ELISA Reader (Tecan Group, Ltd., Männedorf, Switzerland). In addition, serum estradiol contents were measured using the chemiluminescent immunoassay technique with an ECLIA Roche e411 immunoassay analyzer (Roche Diagnostics GmbH, Mannheim, Germany) using the separated serum harvested after the sacrifice of all mice.

Abdominal fat pads, uterus, and liver histological procedures. Sampled tissues were fixed in $10 \%$ neutral buffered formalin (NBF). Following paraffin embedding, 3-4 $\mu \mathrm{m}$ serial sections were prepared. Representative sections were stained with hematoxylin and eosin (H\&E) for light microscopic examination. Furthermore, sections of liver that had been dehydrated in $30 \%$ sucrose solutions were sectioned using a cryostat to stain the lipids with Oil Red O (43). The total thicknesses of abdominal fat pads were measured using an automated image analysis processor (iSolution FL 9.1; IMT i-solution Inc., Quebec, Canada) as mm/mouse. Mean diameters $(\mu \mathrm{m})$ of dorsal abdominal white adipocytes were calculated in restricted view fields on a computer monitor, using an automated image analysis processor. At least 10 white adipocytes per fat pad were used for histomorphometrical analysis according to our previously established methods (43-45). In addition, total full, mucosa, and epithelial thicknesses of the uterus ( $\mu \mathrm{m} /$ uterus) were detected as percentages of uterine glands located in the mucosa (\%/mucosa of uterus) using an automated image analyzer. To observe steatosis in the liver, the percentage of fatty change regions in the hepatic parenchyma was calculated as percentages between one field of the liver $\left(\% / \mathrm{mm}^{2}\right.$ of hepatic parenchyma) under Oil Red O staining. Mean diameters of hepatocytes were calculated in restricted view fields on a computer monitor under $\mathrm{H} \& \mathrm{E}$ staining using an automated image analysis processor, as $\mu \mathrm{m}$; at least 10 hepatocytes per liver were used.

Bone histological procedures. The left sides of each mouse femur were separated and fixed in $10 \% \mathrm{NBF}$, after which they 


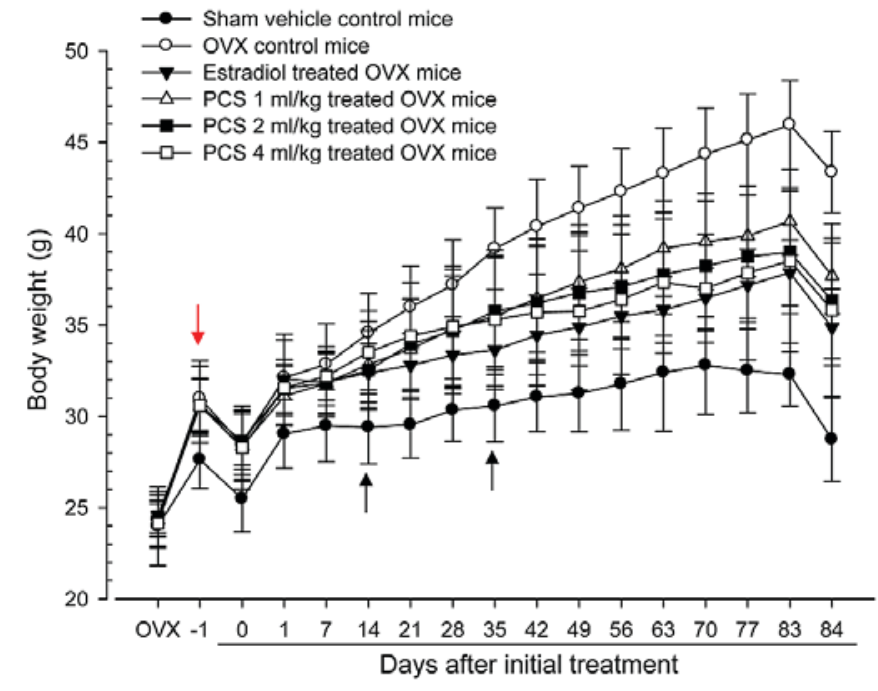

Figure 1. Body weight changes in sham-operated or OVX ddY mice. Values are expressed mean \pm standard deviation $(n=8)$. -1 indicates 1 day before administration was initiated at 27 days after OVX surgery; 0 indicates at the initiated of administration, at 28 days after OVX, 84 indicates 84 days after administration was initiated, at sacrifice. All animals were overnight fasted before OVX, first administration and sacrifice, respectively. OVX, bilateral ovariectomy, PCS, pomegranate concentrated solution.

were decalcified in decalcifying solution $(24.4 \%$ formic acid and $0.5 \mathrm{~N}$ sodium hydroxide) for three days (mixed decalcifying solution was exchanged once a day for three days). Samples were subsequently embedded in paraffin, sectioned (3-4 $\mu \mathrm{m})$, and stained with Safranin-O. In addition, bone histomorphometry was conducted using an automated image analyzer under microscopy (Nikon Corp., Tokyo, Japan) to examine the bone mass and structure with bone resorption in a uniform area of epiphyseal or cortical bone regions of the femur (growth plate regions were excluded). Cortical bone thickness was also measured in the mid-shaft regions of the femur. Trabecular bone volume (TV/BV, TBV; \%), thickness of trabecular bone (Tbt; $\mu \mathrm{m} /$ trabecular bone), number (Tbn; mean numbers of trabecular bone/epiphyseal regions), length ( $\mathrm{Tbl} ; \mathrm{mm} /$ trabecular bone), and cortical bone thickness (Cbt; $\mu \mathrm{m} / \mathrm{mid}$-shaft cortical bone) were measured for bone mass and structure, and osteoclast cell number (Ocn; mean osteoclast cell numbers/ epiphyseal regions) and ratio (OS/BS; $\%$ ) were measured for bone resorption, as described previously $(37,38,46)$.

Statistical analyses. All values for the eight mice in this experiment were expressed as means \pm standard deviation. Multiple comparison tests for the different dose groups were conducted. Variance homogeneity was examined using the Levene test. If the Levene test indicated no significant deviations from variance homogeneity, the data were analyzed using the one-way analysis of variance test followed by the least-significant differences test to determine which group comparisons were significantly different. When significant deviations from variance homogeneity were observed on the Levene test, the non-parametric Kruskal-Wallis test was conducted. When a significant difference was observed on the Kruskal-Wallis test, the Mann-Whitney U test was conducted to determine the specific pairs of groups that were significantly different. Statistical analyses were conducted using the SPSS for Windows software package (ver. 14.0; SPSS Inc., Chicago, IL, USA).

\section{Results}

Significant decreases in body weight were recorded in PCS-treated mice. Significant increases $(\mathrm{P}<0.05$ or $\mathrm{P}<0.01)$ in body weight were detected in all OVX mice compared with control mice (red arrow), with significant $(\mathrm{P}<0.01)$ increases in body weight gains during the 4-week OVX recovery/induction periods. However, significant decreases in body weights were observed in the estradiol group from 14 days after initial treatment, and from 35 days after initial treatment, for all three PCS dosages, compared with OVX control mice (arrows; $\mathrm{P}<0.05$ or $\mathrm{P}<0.01$ ). In addition, all test substance-treated mice exhibited significant decreases in body weight gains during 84 days of treatment compared with OVX controls (Fig. 1).

PCS induced significant decreases in food consumption. OVX mice exhibited significant increases $(\mathrm{P}<0.01)$ in food consumption compared with control mice at all six measurement times $(1,3,7,28,56$ and 83 days after initial administration). However, estradiol subcutaneously-treated mice showed significant decreases $(\mathrm{P}<0.01)$ in food consumption from 7 days after initial treatment, from 28 days after initial administration of 2 and $4 \mathrm{ml} / \mathrm{kg}$ PCS, and from 56 days after initial administration of $1 \mathrm{ml} / \mathrm{kg}$ PCS compared with OVX mice until 83 days after initial administration (Table I).

Significant decreases of abdominal fat padweightwas observed in PCS-treated mice. Significant increases in abdominal fat pad weights deposited in the abdominal cavity, as well as in absolute and relative weights, were observed in OVX mice compared with sham control mice $(\mathrm{P}<0.01)$. However, significant decreases in abdominal fat pad weights were observed in all test substance-treated mice, including estradiol-treated OVX mice, compared with OVX mice $(\mathrm{P}<0.01)$ (Table II). The absolute weights of abdominal fat pads deposited into the abdominal cavity in OVX controls were altered by $2,339.34 \%$ compared with the sham control, and by $-79.29,-42.14,-64.20$ and $-66.65 \%$ in estradiol- and 1-, 2- and 4-ml/kg PCS-treated mice compared with OVX controls, respectively.

Effects on uterus weights. Significant decreases in the uterus absolute and relative wet-weights were observed in OVX mice compared with sham control mice $(\mathrm{P}<0.01)$. However, significant increases in the uterus weights were observed in all test substance-treated mice, including $1 \mathrm{ml} / \mathrm{kg}$ PCS, compared with OVX control mice $(\mathrm{P}<0.01)$ (Table II). Absolute uterine weights of OVX controls were altered by $-88.45 \%$ compared with the sham controls, and by $272.34,39.57,52.77$ and $51.06 \%$ in estradiol and 1-, 2- and 4-ml/kg PCS treated mice, respectively, as compared with OVX controls. Relative uterine weights of OVX were altered by $-92.33 \%$ compared with the sham controls, and by $364.57,61.15,82.57$ and $83.77 \%$ in estradiol- and 1-, 2- and 4-ml/kg PCS treated mice, respectively, as compared with OVX controls. Our results indicated that PCS causes estrogenic activities. 
Table I. Food consumptions in sham-operated or OVX ddY mice.

Food consumption (g/24 h/mouse) on the indicated days after initial treatment

\begin{tabular}{|c|c|c|c|c|c|c|}
\hline Groups & 1 & 3 & 7 & 28 & 56 & 83 \\
\hline \multicolumn{7}{|l|}{ Controls } \\
\hline Sham & $7.36 \pm 0.63$ & $6.39 \pm 0.65$ & $6.46 \pm 0.91$ & $6.66 \pm 0.85$ & $7.41 \pm 0.97$ & $7.63 \pm 0.83$ \\
\hline OVX & $11.55 \pm 1.33^{\mathrm{a}}$ & $11.20 \pm 0.93^{\mathrm{a}}$ & $11.43 \pm 1.05^{\mathrm{a}}$ & $11.63 \pm 1.04^{\mathrm{a}}$ & $12.92 \pm 1.45^{\mathrm{a}}$ & $14.94 \pm 1.46^{\mathrm{a}}$ \\
\hline Estradiol & $11.66 \pm 1.29^{\mathrm{a}}$ & $10.64 \pm 1.03^{\mathrm{a}}$ & $9.74 \pm 0.99^{\mathrm{a}, \mathrm{b}}$ & $9.64 \pm 1.13^{\mathrm{a}, \mathrm{b}}$ & $10.34 \pm 0.92^{\mathrm{a}, \mathrm{b}}$ & $10.73 \pm 1.57^{\mathrm{a}, \mathrm{b}}$ \\
\hline \multicolumn{7}{|l|}{ PCS } \\
\hline $1 \mathrm{ml} / \mathrm{kg}$ & $11.73 \pm 0.97^{\mathrm{a}}$ & $10.87 \pm 0.78^{a}$ & $10.69 \pm 0.92^{\mathrm{a}}$ & $10.82 \pm 0.77^{\mathrm{a}}$ & $11.06 \pm 0.87^{\mathrm{a}, \mathrm{b}}$ & $12.50 \pm 0.79^{a, b}$ \\
\hline $2 \mathrm{ml} / \mathrm{kg}$ & $11.47 \pm 1.35^{\mathrm{a}}$ & $11.00 \pm 1.34^{\mathrm{a}}$ & $10.77 \pm 0.88^{a}$ & $10.55 \pm 0.69^{\mathrm{a}, \mathrm{c}}$ & $10.62 \pm 0.60^{\mathrm{a}, \mathrm{b}}$ & $11.42 \pm 1.06^{\mathrm{a}, \mathrm{b}}$ \\
\hline $4 \mathrm{ml} / \mathrm{kg}$ & $11.66 \pm 1.53^{\mathrm{a}}$ & $11.18 \pm 1.18^{\mathrm{a}}$ & $10.85 \pm 0.90^{\mathrm{a}}$ & $10.36 \pm 0.73^{\mathrm{a}, \mathrm{b}}$ & $10.47 \pm 0.88^{\mathrm{a}, \mathrm{b}}$ & $11.31 \pm 1.65^{\mathrm{a}, \mathrm{b}}$ \\
\hline
\end{tabular}

Values are expressed mean \pm standard deviation $(n=8)$. Three different dosages of PCS were orally administered, and $17 \beta$-estradiol was subcutaneously injected at a dose of $0.03 \mu \mathrm{g} /$ head on the dorsal back skins, once a day for 84 days from 28 days after OVX surgery. ${ }^{\mathrm{a} P}<0.01 \mathrm{vs}$. sham control; ${ }^{\mathrm{b}} \mathrm{P}<0.01$ and ${ }^{\mathrm{c}} \mathrm{P}<0.05$ vs. OVX control, determined by least significant difference test. OVX, bilateral ovariectomy; PCS, pomegranate concentrated solution.

Table II. Abdominal fat pad, uerus and liver weights in sham-operated or OVX ddY mice.

\begin{tabular}{|c|c|c|c|c|c|c|}
\hline \multirow[b]{2}{*}{ Groups } & \multicolumn{3}{|c|}{ Absolute wet-weight of organ $(\mathrm{g})$} & \multicolumn{3}{|c|}{ Relative wet-weight of organ (\% of body weight) } \\
\hline & Abdominal fat pad & Uterus & Liver & Abdominal fat pad & Uterus & Liver \\
\hline \multicolumn{7}{|l|}{ Controls } \\
\hline Sham & $0.140 \pm 0.103$ & $0.254 \pm 0.079$ & $1.240 \pm 0.259$ & $0.499 \pm 0.384$ & $0.885 \pm 0.277$ & $4.316 \pm 0.799$ \\
\hline OVX & $3.403 \pm 0.486^{c}$ & $0.029 \pm 0.008^{c}$ & $1.232 \pm 0.193$ & $7.821 \pm 0.802^{\mathrm{a}}$ & $0.068 \pm 0.018^{c}$ & $2.842 \pm 0.434^{\mathrm{a}}$ \\
\hline Estradiol & $0.705 \pm 0.572^{\mathrm{d}, \mathrm{g}}$ & $0.109 \pm 0.039^{\mathrm{c}, \mathrm{g}}$ & $1.337 \pm 0.084$ & $2.052 \pm 1.706^{\mathrm{b}, \mathrm{e}}$ & $0.315 \pm 0.119^{c, g}$ & $3.845 \pm 0.341^{\mathrm{e}}$ \\
\hline \multicolumn{7}{|l|}{ PCS } \\
\hline $1 \mathrm{ml} / \mathrm{kg}$ & $1.969 \pm 0.754^{\mathrm{c}, \mathrm{g}}$ & $0.041 \pm 0.008^{\mathrm{c}, \mathrm{h}}$ & $1.302 \pm 0.076$ & $5.207 \pm 1.873^{\mathrm{a}, \mathrm{e}}$ & $0.109 \pm 0.023^{\mathrm{c}, \mathrm{g}}$ & $3.461 \pm 0.261^{\mathrm{a}, \mathrm{f}}$ \\
\hline $2 \mathrm{ml} / \mathrm{kg}$ & $1.218 \pm 0.480^{\mathrm{c}, \mathrm{g}}$ & $0.045 \pm 0.009^{\mathrm{c}, \mathrm{g}}$ & $1.319 \pm 0.071$ & $3.319 \pm 1.169^{\mathrm{a}, \mathrm{e}}$ & $0.124 \pm 0.024^{\mathrm{c}, \mathrm{g}}$ & $3.659 \pm 0.445^{\mathrm{b}, \mathrm{e}}$ \\
\hline $4 \mathrm{ml} / \mathrm{kg}$ & $1.135 \pm 0.198^{\mathrm{c}, \mathrm{g}}$ & $0.044 \pm 0.011^{\mathrm{c}, \mathrm{g}}$ & $1.312 \pm 0.057$ & $3.249 \pm 0.894^{\mathrm{a}, \mathrm{e}}$ & $0.125 \pm 0.033^{\mathrm{c}, \mathrm{g}}$ & $3.719 \pm 0.517^{\mathrm{b}, \mathrm{e}}$ \\
\hline
\end{tabular}

Values are expressed mean \pm standard deviation $(n=8)$. Three different dosages of PCS were orally administered, and $17 \beta$-estradiol was subcutaneously injected at a dose of $0.03 \mu \mathrm{g}$ /head on the dorsal back skins, once a day for 84 days from 28 days after OVX surgery. ${ }^{\mathrm{P}} \mathrm{P}<0.01$ and ${ }^{\mathrm{b}} \mathrm{P}<0.05$ vs. sham control, determined by LSD test; ${ }^{\mathrm{C}} \mathrm{P}<0.01$ and ${ }^{\mathrm{d}} \mathrm{P}<0.05$ vs. sham control, determined by $\mathrm{MW}$ test; ${ }^{\mathrm{e}} \mathrm{P}<0.01$ and ${ }^{\mathrm{f}} \mathrm{P}<0.05$ vs . OVX control by LSD test; ${ }^{\mathrm{g}} \mathrm{P}<0.01$ and ${ }^{\mathrm{h}} \mathrm{P}<0.05$ vs. OVX control by MW test. OVX, bilateral ovariectomy, PCS, pomegranate concentrated solution; LSD, least significant difference; MW, Mann-Whitney U.

Significant increases in liver weight were observed in $P C S$-treated mice. Significant decreases in the liver relative wet-weights were detected in OVX mice compared with sham control mice $(\mathrm{P}<0.01)$; however, significant increases in the liver relative weights were observed in all test substance-treated mice, including all three different dosages of PCS, compared with OVX mice $(\mathrm{P}<0.05$ or $\mathrm{P}<0.01)$. Estradiol- and $1-, 2-$ and 4-ml/kg PCS-treated mice did not exhibit any significant changes in absolute liver weights compared with OVX control mice, or in OVX mice compared with sham control mice (Table II). These data suggested that PCS exerts hepatoprotective effects.

Significant increases in femur weight were detected in PCStreated mice. Significant decreases in the femur relative wet-weights and absolute and relative dry and ash weights were observed in OVX mice compared with sham control mice $(\mathrm{P}<0.01)$. However, significant increases in the femur wet relative weights and dry and ash absolute and relative weights were observed in all test substance-treated mice, including estradiol treated mice, compared with OVX mice $(\mathrm{P}<0.05$ and $\mathrm{P}<0.01)$ (Table III). Our observations indicated that PCS has anti-osteoporosis activities.

Changes of serum biochemistry indices were induced by PCS-treatment. Significant increases in serum AST, ALT, TC, LDL and TG levels and significant decreases in serum HDL levels were observed in OVX control mice compared with sham control mice. However, significant decreases in serum AST, ALT, TC, LDL and TG levels and significant increases in serum HDL levels were observed in all test material-treated mice, including $1 \mathrm{ml} / \mathrm{kg}$ PCS-treated mice, compared with 
Table III. Right femur weights in sham-operated or OVX ddY mice.

\begin{tabular}{|c|c|c|c|c|c|c|}
\hline \multirow[b]{2}{*}{ Groups } & \multicolumn{3}{|c|}{ Absolute weight (g) } & \multicolumn{3}{|c|}{ Relative weight ( $\%$ of body weight) } \\
\hline & Wet & Dry & Ash & Wet & Dry & Ash \\
\hline \multicolumn{7}{|l|}{ Controls } \\
\hline Sham & $0.094 \pm 0.006$ & $0.065 \pm 0.004$ & $0.039 \pm 0.003$ & $0.327 \pm 0.025$ & $0.229 \pm 0.024$ & $0.137 \pm 0.019$ \\
\hline OVX & $0.089 \pm 0.007$ & $0.051 \pm 0.003^{\mathrm{a}}$ & $0.026 \pm 0.003^{\mathrm{a}}$ & $0.205 \pm 0.010^{\mathrm{b}}$ & $0.118 \pm 0.010^{\mathrm{a}}$ & $0.059 \pm 0.007^{\mathrm{a}}$ \\
\hline Estradiol & $0.095 \pm 0.010$ & $0.059 \pm 0.003^{\mathrm{a}, \mathrm{c}}$ & $0.034 \pm 0.004^{\mathrm{a}, \mathrm{c}}$ & $0.273 \pm 0.038^{\mathrm{b}, \mathrm{e}}$ & $0.170 \pm 0.012^{\mathrm{a}, \mathrm{c}}$ & $0.098 \pm 0.013^{\mathrm{a}, \mathrm{c}}$ \\
\hline \multicolumn{7}{|l|}{ PCS } \\
\hline $1 \mathrm{ml} / \mathrm{kg}$ & $0.091 \pm 0.005$ & $0.054 \pm 0.003^{\mathrm{a}, \mathrm{d}}$ & $0.032 \pm 0.004^{\mathrm{a}, \mathrm{c}}$ & $0.240 \pm 0.010^{\mathrm{b}, \mathrm{e}}$ & $0.145 \pm 0.012^{\mathrm{a}, \mathrm{c}}$ & $0.086 \pm 0.011^{\mathrm{a}, \mathrm{c}}$ \\
\hline $2 \mathrm{ml} / \mathrm{kg}$ & $0.095 \pm 0.008$ & $0.056 \pm 0.003^{\mathrm{a}, \mathrm{c}}$ & $0.033 \pm 0.004^{\mathrm{a}, \mathrm{c}}$ & $0.263 \pm 0.024^{\mathrm{b}, \mathrm{e}}$ & $0.156 \pm 0.017^{\mathrm{a}, \mathrm{c}}$ & $0.091 \pm 0.009^{\mathrm{a}, \mathrm{c}}$ \\
\hline $4 \mathrm{ml} / \mathrm{kg}$ & $0.092 \pm 0.007$ & $0.056 \pm 0.004^{\mathrm{a}, \mathrm{c}}$ & $0.033 \pm 0.003^{\mathrm{a}, \mathrm{c}}$ & $0.261 \pm 0.043^{\mathrm{b}, \mathrm{e}}$ & $0.158 \pm 0.020^{\mathrm{a}, \mathrm{c}}$ & $0.093 \pm 0.013^{\mathrm{a}, \mathrm{c}}$ \\
\hline
\end{tabular}

Values are expressed mean \pm standard deviation $(\mathrm{n}=8)$. ${ }^{\mathrm{a}} \mathrm{P}<0.01 \mathrm{vs}$. sham control by LSD test. ${ }^{\mathrm{b}} \mathrm{P}<0.01 \mathrm{vs}$. sham control by $\mathrm{MW}$ test. ${ }^{\mathrm{c}} \mathrm{P}<0.01$ and ${ }^{\mathrm{d}} \mathrm{P}<0.05$ vs. OVX control by least significant difference test. ${ }^{\mathrm{e}} \mathrm{P}<0.01$ vs. OVX control by MW test. Three different dosages of PCS were orally administered, and $17 \beta$-estradiol was subcutaneously injected at a dose of $0.03 \mu \mathrm{g} /$ head on the dorsal back skins, once a day for 84 days from 28 days after OVX surgery. OVX, bilateral ovariectomy; PCS, pomegranate concentrated solution; MW, Mann-Whitney U.

Table IV. Serum biochemistry: AST, ALT, TC, LDL, HDL and TG Levels in sham-operated or OVX ddY mice.

\begin{tabular}{lcccccc}
\hline \multirow{7}{*}{ Groups } & \multicolumn{7}{c}{ Serum biochemical values } \\
\cline { 2 - 7 } & AST (U/l) & ALT (U/l) & TC (mg/dl) & LDL (mg/dl) & HDL (mg/dl) & TG (mg/dl) \\
\hline Controls & & & & & \\
Sham & $84.88 \pm 14.56$ & $38.25 \pm 12.07$ & $92.25 \pm 18.81$ & $64.00 \pm 10.61$ & $94.88 \pm 12.84$ & $37.88 \pm 11.67$ \\
OVX & $162.75 \pm 15.78^{\mathrm{a}}$ & $77.38 \pm 9.07^{\mathrm{a}}$ & $181.63 \pm 19.00^{\mathrm{a}}$ & $182.50 \pm 18.62^{\mathrm{a}}$ & $46.25 \pm 11.94^{\mathrm{a}}$ & $154.00 \pm 24.68^{\mathrm{b}}$ \\
Estradiol & $108.00 \pm 13.65^{\mathrm{a}, \mathrm{c}}$ & $53.13 \pm 9.22^{\mathrm{a}, \mathrm{c}}$ & $134.75 \pm 21.73^{\mathrm{a}, \mathrm{c}}$ & $134.75 \pm 11.47^{\mathrm{a}, \mathrm{c}}$ & $70.50 \pm 12.69^{\mathrm{a}, \mathrm{c}}$ & $101.00 \pm 19.13^{\mathrm{b}, \mathrm{e}}$ \\
PCS & & & & & & \\
$1 \mathrm{ml} / \mathrm{kg}$ & $141.38 \pm 8.93^{\mathrm{a}, \mathrm{c}}$ & $62.38 \pm 10.03^{\mathrm{a}, \mathrm{c}}$ & $152.50 \pm 15.74^{\mathrm{a}, \mathrm{c}}$ & $156.00 \pm 6.32^{\mathrm{a}, \mathrm{c}}$ & $61.88 \pm 8.17^{\mathrm{a}, \mathrm{d}}$ & $123.50 \pm 11.34^{\mathrm{b}, \mathrm{f}}$ \\
$2 \mathrm{ml} / \mathrm{kg}$ & $126.25 \pm 8.86^{\mathrm{a}, \mathrm{c}}$ & $58.38 \pm 7.89^{\mathrm{a}, \mathrm{c}}$ & $143.38 \pm 11.56^{\mathrm{a}, \mathrm{c}}$ & $144.75 \pm 14.59^{\mathrm{a}, \mathrm{c}}$ & $67.75 \pm 12.09^{\mathrm{a}, \mathrm{c}}$ & $109.88 \pm 16.50^{\mathrm{b}, \mathrm{e}}$ \\
$4 \mathrm{ml} / \mathrm{kg}$ & $125.88 \pm 11.24^{\mathrm{a}, \mathrm{c}}$ & $58.50 \pm 9.27^{\mathrm{a}, \mathrm{c}}$ & $142.50 \pm 13.67^{\mathrm{a}, \mathrm{c}}$ & $144.38 \pm 19.38^{\mathrm{a}, \mathrm{c}}$ & $68.25 \pm 14.89^{\mathrm{a}, \mathrm{c}}$ & $109.00 \pm 25.48^{\mathrm{b}, \mathrm{c}}$ \\
\hline
\end{tabular}

Values are expressed mean \pm standard deviation $(\mathrm{n}=8) .{ }^{\mathrm{a}} \mathrm{P}<0.01 \mathrm{vs}$. sham control, determined by LSD test; ${ }^{\mathrm{b}} \mathrm{P}<0.01 \mathrm{vs}$. sham control, determined by MW test; ${ }^{\mathrm{c}} \mathrm{P}<0.01$ and ${ }^{\mathrm{d}} \mathrm{P}<0.05$ vs. OVX control, determined by LSD test; ${ }^{\mathrm{e}} \mathrm{P}<0.01$ and ${ }^{\mathrm{f}} \mathrm{P}<0.05$ vs. OVX control, determined by MW test. Three different dosages of PCS were orally administered, and 17 $\beta$-estradiol was subcutaneously injected at a dose of $0.03 \mu \mathrm{g} / \mathrm{head}$ on the dorsal back skins, once a day for 84 days from 28 days after OVX surgery. OVX, bilateral ovariectomy; PCS, pomegranate concentrated solution; ALT, alanine aminotransferase. AST, aspartate aminotransferase; LDL, low density lipoprotein; TC, total cholesterol; TG, triglyceride; HDL, high density lipoprotein; LSD, least significant difference; MW, Mann-Whitney U.

OVX mice (Table IV). These results demonstrated that PCS causes hepatoprotective and hypolipidemic effects.

Significant decreases in serum estradiol levels in OVX mice were observed compared with sham control mice $(\mathrm{P}<0.01)$. However, significant increases in serum estradiol levels were observed in all test substance-treated mice, including $4 \mathrm{ml} / \mathrm{kg}$ PCS-treated mice, as compared with OVX mice $(\mathrm{P}<0.01)$ (Fig. 2). Serum estradiol levels in OVX were altered by $-74.27 \%$ compared with sham controls, and by 199.08 , $47.69,94.64$ and $95.19 \%$ in estradiol- and 1-, 2- and 4-ml/kg PCS-treated mice, respectively, compared with OVX controls. Our results indicated that PCS causes estrogenic activities.

Significant increases in serum osteocalcin levels, and significant decreases in serum bALP levels, were detected in OVX mice compared with sham control mice $(\mathrm{P}<0.01)$.
However, significant decreases in serum osteocalcin and increases in bALP levels were observed in all test material-treated mice, including estradiol-treated mice, compared with OVX control mice (Figs. 3 and 4). Serum osteocalcin and bALP levels in OVX were altered by 82.59 and $-45.63 \%$ compared with sham controls, and by $-33.92,-21.60,-27.99$ and $-28.20 \%$ (for serum osteocalcin levels) and 46.16, 25.32, 39.04 and $40.14 \%$ (for serum bALP levels) in estradiol- and 1-, 2- and 4-ml/kg PCS-treated mice, respectively, as compared with OVX controls. Our observations indicated that PCS has anti-osteoporosis activities.

Significant increases of BMD were recorded in PCS-treated mice. The total body and femur mean BMD of OVX mice were significantly decreased compared with sham control 


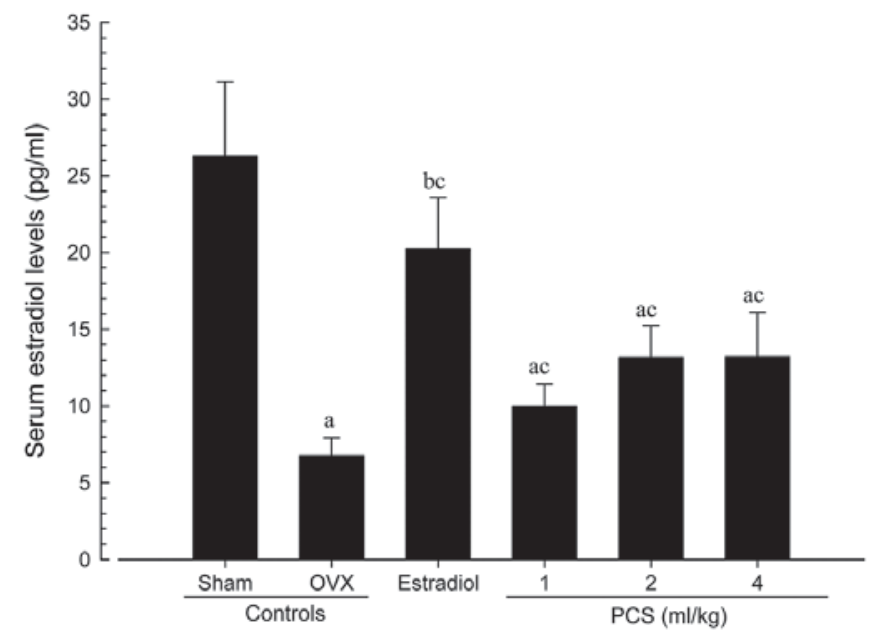

Figure 2. Serum estradiol levels in sham-operated or OVX ddY mice. Values are expressed mean \pm standard deviation $(\mathrm{n}=8) .{ }^{\mathrm{a}} \mathrm{P}<0.01$ and ${ }^{\mathrm{b}} \mathrm{P}<0.05$ vs. sham control; ${ }^{\mathrm{C}} \mathrm{P}<0.01$ vs.OVX control, determined by Mann-Whitney U test. OVX, bilateral ovariectomy; PCS, pomegranate concentrated solution.

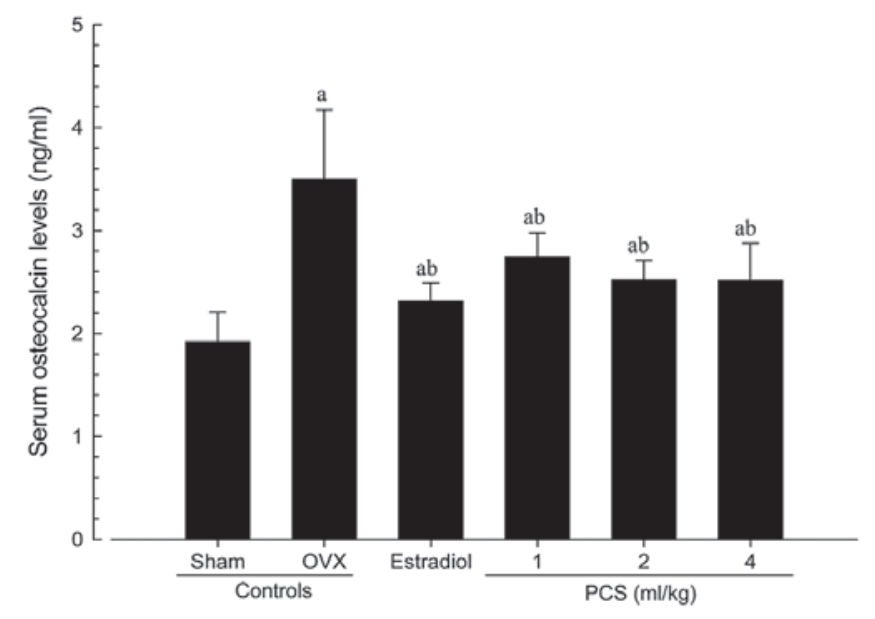

Figure 3. Serum osteocalcin levels in sham-operated or OVX ddY mice Values are expressed mean \pm standard deviation $(\mathrm{n}=8)$. ${ }^{\mathrm{a}} \mathrm{P}<0.01$ vs. sham control; ${ }^{b} \mathrm{P}<0.01$ vs. OVX control, determined by Mann-Whitney U test. OVX, bilateral ovariectomy; PCS, pomegranate concentrated solution.

mice $(\mathrm{P}<0.01)$. However, significant increases in total body and femur mean BMD were detected in estradiol- and PCS (all three different dosages)-treated mice compared with OVX mice $(\mathrm{P}<0.01)$ (Table V; Fig. 5). The total body mean BMD of OVX controls were altered by $-14.80 \%$ compared with sham controls, and by $11.23,5.26,10.18$ and $10.64 \%$ in estradioland 1-, 2-, and 4-ml/kg PCS treated mice, respectively, as compared with OVX controls. The total femur mean BMD of OVX was changed by $-13.73 \%$ compared with sham controls, and by $12.20,3.51,6.96$ and $7.12 \%$ in estradiol- and 1-, 2-, and $4-\mathrm{ml} / \mathrm{kg}$ PCS-treated mice, respectively, as compared with OVX controls. Our results showed that PCS exerts anti-osteoporosis activities.

Significant decreases of body fat densities in PCS-treated mice. Total body and abdominal fat densities of OVX control mice were significantly increased, as compared with sham

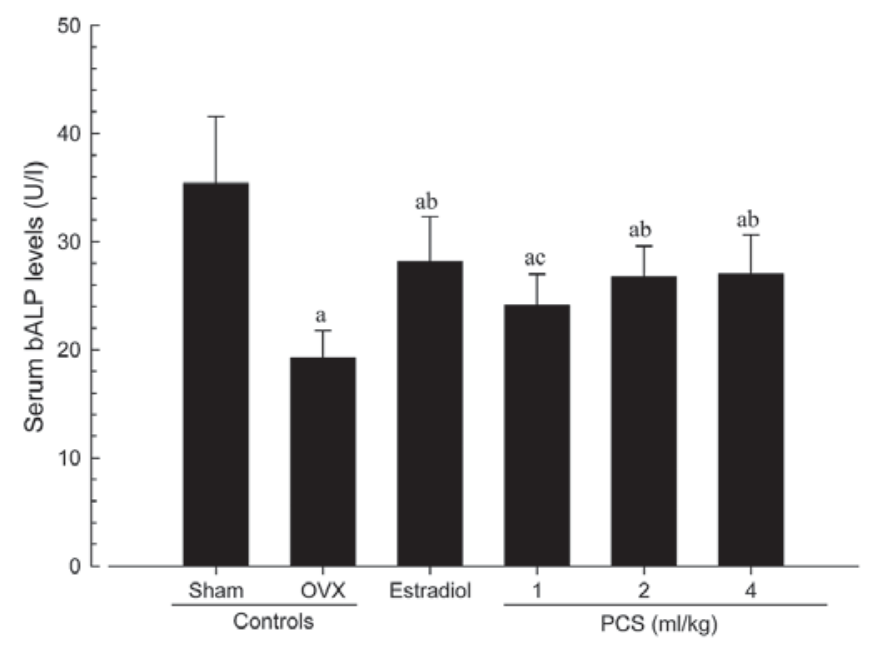

Figure 4. Serum bALP Levels in Sham-operated or OVX ddY Mice. Values are expressed mean \pm standard deviation $(n=8)$. ${ }^{a} \mathrm{P}<0.01$ vs. sham control; ${ }^{b} \mathrm{P}<0.01$ and ${ }^{\mathrm{c}} \mathrm{P}<0.05$ vs. OVX control, determined by least significant difference test. OVX, bilateral ovariectomy, PCS, pomegranate concentrated solution; bALP, bone specific alkaline phosphatase.

control mice $(\mathrm{P}<0.01)$. However, significant decreases in total body and abdominal fat densities were detected in all test substance-administrated mice, including subcutaneous estradiol-treated mice, as compared with OVX control mice $(\mathrm{P}<0.01)$ (Table V). The total mean body fat densities of OVX controls were altered by $211.77 \%$ compared with sham controls, and by $-31.65,-17.33,-27.47$ and $-27.64 \%$ in estradiol- and 1-, 2- and 4-ml/kg PCS-treated mice, respectively, as compared with OVX controls. The mean abdominal fat densities of OVX controls were altered by $275.16 \%$ compared with sham controls, and by $-35.88,-28.29,-35.68$ and $-35.73 \%$ in estradiol- and 1-, 2- and 4-ml/kg PCS-treated mice, respectively, as compared with OVX controls. These results indicated that PCS exerts anti-obese actions.

Significant increases of bone strength in PCS-treated mice. The strengths of femur mid-shaft regions in OVX control mice, determined as FL, were significantly decreased compared with sham control mice $(\mathrm{P}<0.01)$; however, significant increases in FL on the femur were detected in all test substance-administrated mice including $1 \mathrm{ml} / \mathrm{kg}$ PCS-treated mice compared with OVX control mice $(\mathrm{P}<0.05$ or $\mathrm{P}<0.01)$ (Fig. 6). The FL in the femur mid-shaft regions of OVX control were altered by $-53.05 \%$ compared with sham controls, and by $68.69,33.74,55.99$, and $56.74 \%$ in estradiol- and 1-, 2- and 4-ml/kg PCS-treated mice, respectively, as compared with OVX controls. Our data indicated that PCS causes anti-osteoporosis activities.

Changes in abdominal fat pad, uterus, and liver histopathology. Significant increases in the thickness of abdominal fat pads deposited into the abdominal cavity and the mean adipocyte diameters were observed in OVX mice due to the deposition in adipose tissues in the abdominal cavity and the hypertrophy of adipocytes, respectively $(\mathrm{P}<0.01)$. However, significant decreases in the thickness of abdominal fat pads and their mean diameters of adipocytes were detected in all test substance-administrated mice, including estradiol 
Table V. Bone mineral density and body fat density in sham-operated or OVX ddY mice.

\begin{tabular}{|c|c|c|c|c|}
\hline \multirow{2}{*}{$\begin{array}{l}\text { Variable } \\
\text { Groups }\end{array}$} & \multicolumn{2}{|c|}{ Bone mineral density $\left(\mathrm{g} / \mathrm{cm}^{2}\right)$} & \multicolumn{2}{|c|}{ Fat density ( $\%$ of body mass) } \\
\hline & Total body & Right femur & Total body & Abdominal cavity \\
\hline \multicolumn{5}{|l|}{ Controls } \\
\hline Sham & $0.0251 \pm 0.0011$ & $0.0269 \pm 0.0007$ & $11.31 \pm 2.10$ & $11.17 \pm 1.65$ \\
\hline OVX & $0.0214 \pm 0.0006^{\mathrm{a}}$ & $0.0232 \pm 0.0005^{\mathrm{a}}$ & $35.27 \pm 3.47^{\mathrm{a}}$ & $41.91 \pm 4.40^{\mathrm{c}}$ \\
\hline Estradiol & $0.0238 \pm 0.0006^{\mathrm{a}, \mathrm{b}}$ & $0.0260 \pm 0.0008^{\mathrm{b}}$ & $24.10 \pm 3.46^{\mathrm{a}, \mathrm{b}}$ & $26.87 \pm 4.30^{\mathrm{c}, \mathrm{d}}$ \\
\hline \multicolumn{5}{|l|}{ PCS } \\
\hline $1 \mathrm{ml} / \mathrm{kg}$ & $0.0225 \pm 0.0004^{\mathrm{a}, \mathrm{b}}$ & $0.0240 \pm 0.0004^{\mathrm{a}}$ & $29.16 \pm 2.89^{\mathrm{a}, \mathrm{b}}$ & $30.05 \pm 7.21^{\mathrm{c}, \mathrm{d}}$ \\
\hline $2 \mathrm{ml} / \mathrm{kg}$ & $0.0236 \pm 0.0009^{\mathrm{a}, \mathrm{b}}$ & $0.0248 \pm 0.0014^{\mathrm{a}, \mathrm{b}}$ & $25.58 \pm 6.22^{\mathrm{a}, \mathrm{b}}$ & $26.96 \pm 7.07^{\mathrm{c}, \mathrm{d}}$ \\
\hline $4 \mathrm{ml} / \mathrm{kg}$ & $0.0237 \pm 0.0009^{\mathrm{a}, \mathrm{b}}$ & $0.0248 \pm 0.0013^{\mathrm{a}, \mathrm{b}}$ & $25.52 \pm 5.90^{\mathrm{a}, \mathrm{b}}$ & $26.94 \pm 9.07^{\mathrm{c}, \mathrm{d}}$ \\
\hline
\end{tabular}

Values are expressed mean \pm standard deviation $(\mathrm{n}=8) .{ }^{\mathrm{a}} \mathrm{P}<0.01 \mathrm{vs}$. sham control by LSD test; ${ }^{\mathrm{b}} \mathrm{P}<0.01 \mathrm{vs}$. OVX control by LSD test; ${ }^{\mathrm{c}} \mathrm{P}<0.01 \mathrm{vs}$. sham control by MW test; ${ }^{\mathrm{d}} \mathrm{P}<0.01 \mathrm{vs}$. OVX control by MW test. Three different dosages of PCS were orally administered, and $17 \beta$-estradiol was subcutaneously treated at a dose of $0.03 \mu \mathrm{g} /$ head on the dorsal back skins, once a day for 84 days from 28 days after OVX surgery. OVX, bilateral ovariectomy; PCS, pomegranate concentrated solution; LSD, least significant difference; MW, Mann-Whitney U.

A

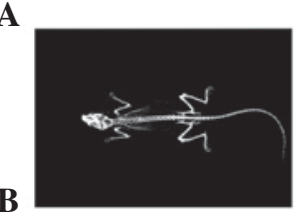

B

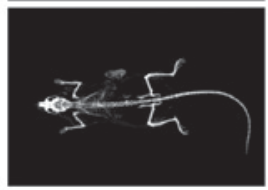

C

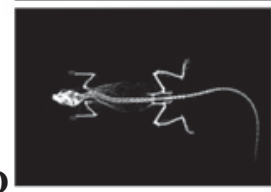

D

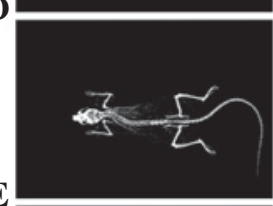

$\mathbf{E}$
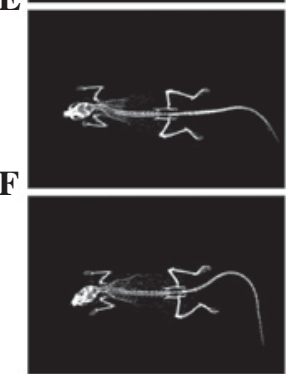
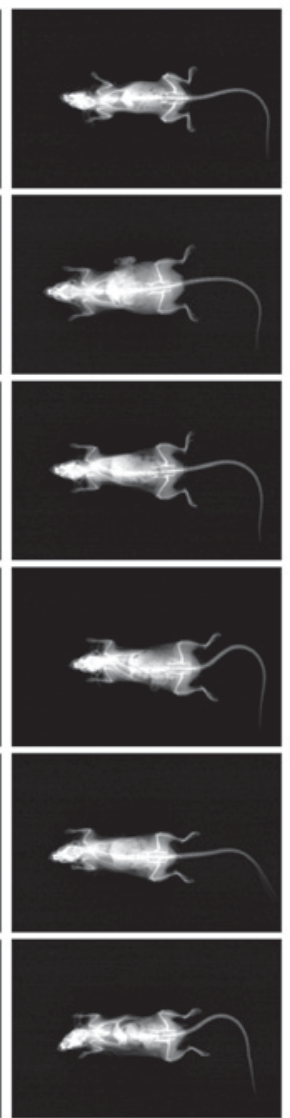
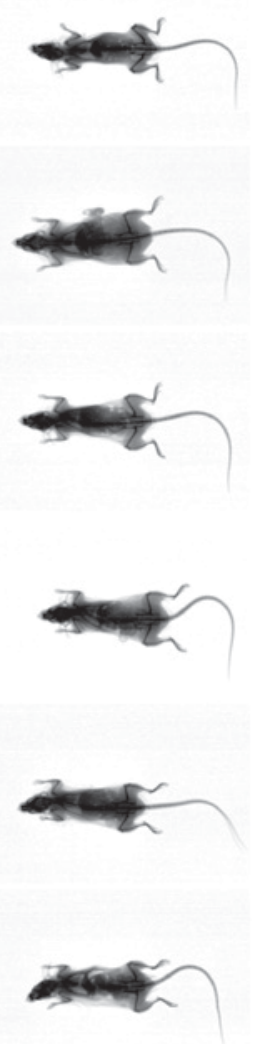

Figure 5. Representative whole body DEXA images captured from sham-operated or OVX ddY mice. (A) Sham-operated and distilled water-treated sham vehicle control mice; (B) distilled water-treated OVX control mice; (C) $17 \beta$-estradiol (0.03 $\mu \mathrm{g} / \mathrm{head})$-treated OVX mice; (D) $1 \mathrm{ml} / \mathrm{kg}$ PCS-treated OVX mice; (E) $2 \mathrm{ml} / \mathrm{kg}$ PCS-treated OVX mice; and (F) $4 \mathrm{ml} / \mathrm{kg}$ PCS-treated OVX mice. OVX, bilateral ovariectomy, PCS, pomegranate concentrated solution; DEXA, dual-energy $\mathrm{x}$-ray absorptionmetry.

treated mice, compared with OVX control mice $(\mathrm{P}<0.01)$ (Table VI; Fig. 7). Significant decreases in total, mucosa,

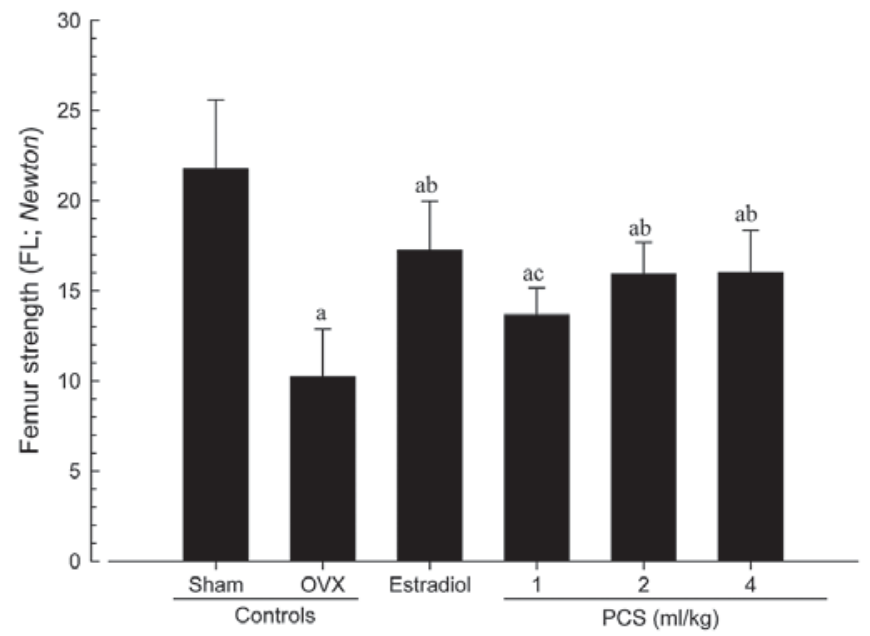

Figure 6. Femur FL in sham-operated or OVX ddY mice. Values are expressed mean \pm standard deviation $(\mathrm{n}=8)$. ${ }^{\mathrm{a}} \mathrm{P}<0.01$ vs. sham control; ${ }^{\mathrm{b}} \mathrm{P}<0.01$ and ${ }^{\mathrm{c}} \mathrm{P}<0.05$ vs. OVX control, determined by least significant difference test. OVX, bilateral ovariectomy; PCS, pomegranate concentrated solution, FL, failure load.

and epithelial thicknesses of the uterus, and in the percentages of uterine glands in the mucosa, were observed in OVX control mice due to estrogen depletion-related atrophic changes. However, significant increases in total, mucosa, and epithelial thicknesses of the uterus, as well as in the percentages of uterine glands in the mucosa, were detected in estradiol- and 1-, 2- and 4-ml/kg PCS-treated mice, respectively, as compared with OVX control mice $(\mathrm{P}<0.01)$ (Table VI; Fig. 8). Furthermore, significant increases in the percentage of fatty change regions and the mean diameters of hepatocytes were observed in OVX control mice $(\mathrm{P}<0.01)$. This was thought to be due to the deposition of lipids into hepatocytes and steatosis. However, significant decreases in the percentage of fatty change regions and mean diameters of hepatocytes were detected in all test substance-administered mice in the present study, including estradiol-treated mice, as 


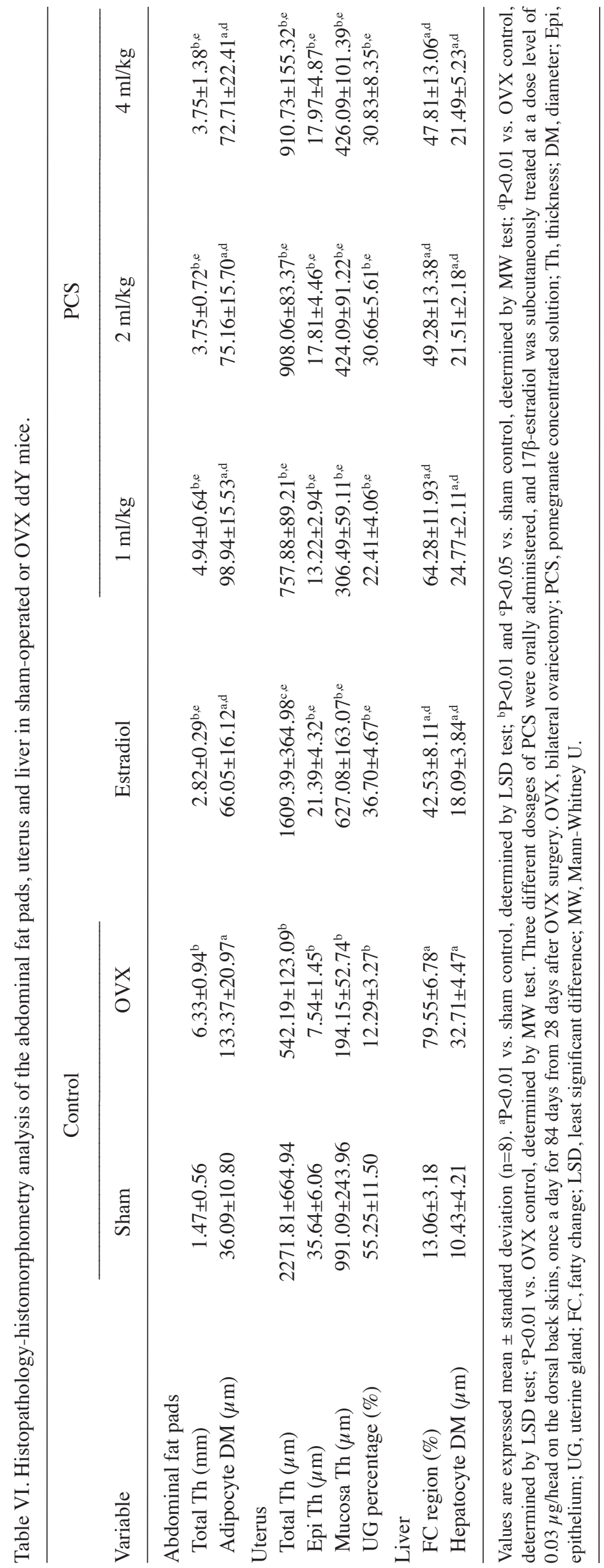



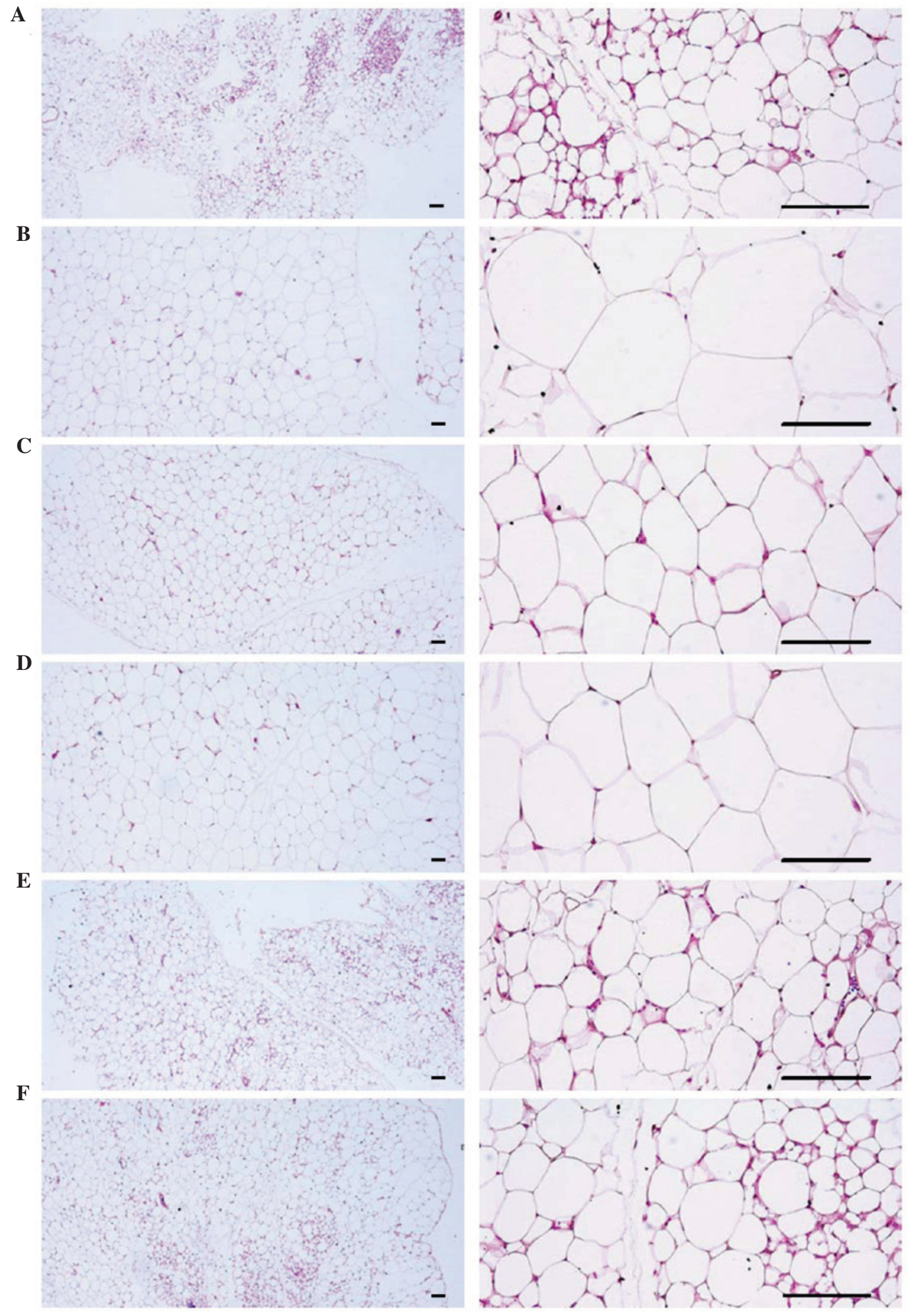

Figure 7. Representative histological images of adipocytes, captured from sham-operated or OVX ddY mice abdominal fat pads deposited in abdominal cavity after hemotoxylin and eosin staining. (A) Sham-operated and distilled water-treated sham vehicle control mice; (B) distilled water-treated OVX control mice; (C) 17ß-estradiol (0.03 $\mu \mathrm{g} / \mathrm{head})$-treated OVX mice; (D) PCS (1 ml/kg)-treated OVX mice; (E) PCS (2 ml/kg)-treated OVX mice; (F) PCS (4 ml/kg)-treated OVX mice. OVX, bilateral ovariectomy; PCS, pomegranate concentrated solution. Scale bar, $120 \mu \mathrm{m}$.

compared with OVX control mice (Table VI; Fig. 9). These results suggested that PCS exerts anti-obesity, estrogenic and hepatoprotective effects.
Effects on femur histopathology. Although relatively well-developed trabecular and cortical bone were observed in the femur of sham control mice, classical osteoporotic 
A
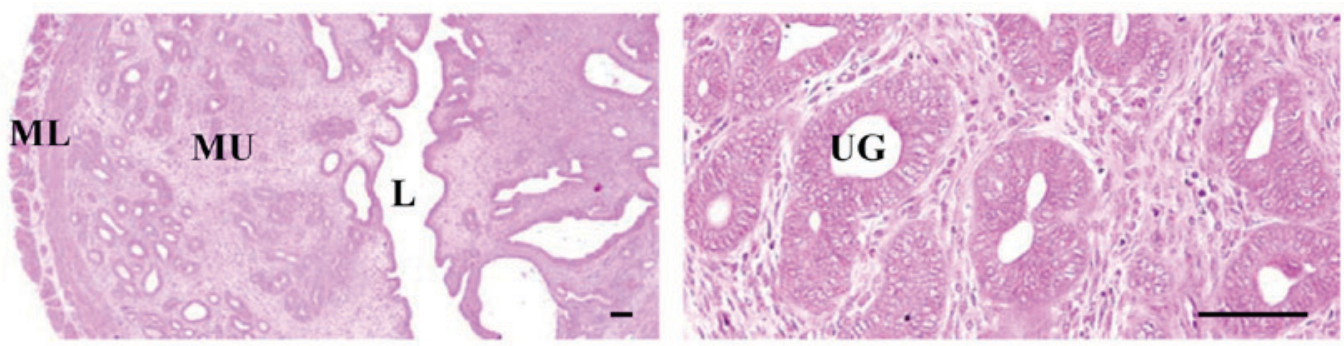

B
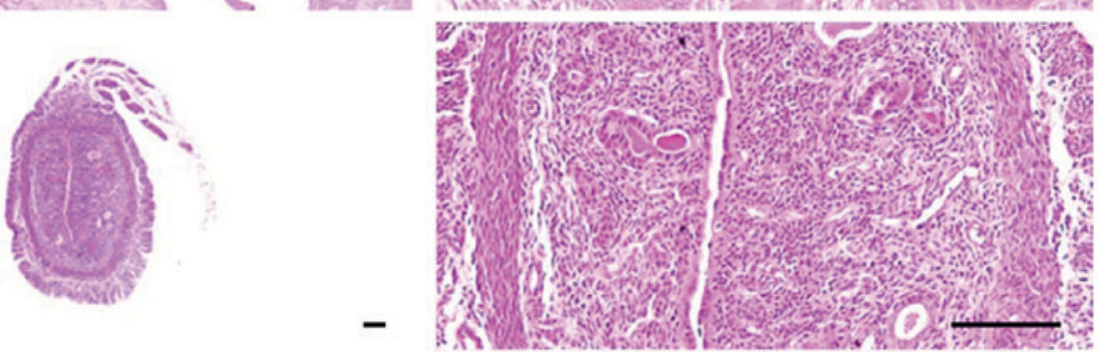

C
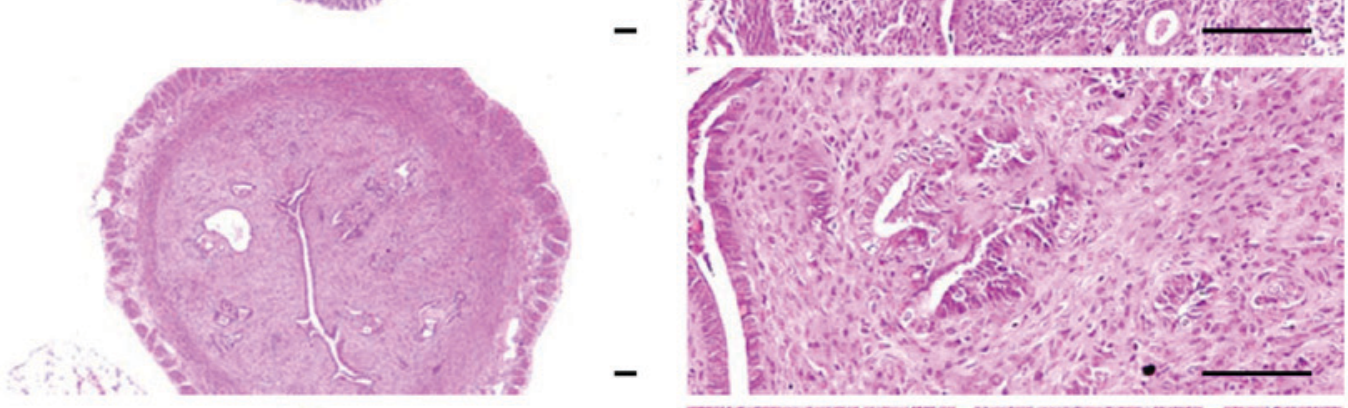

D

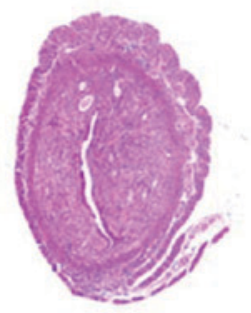

$\mathbf{E}$

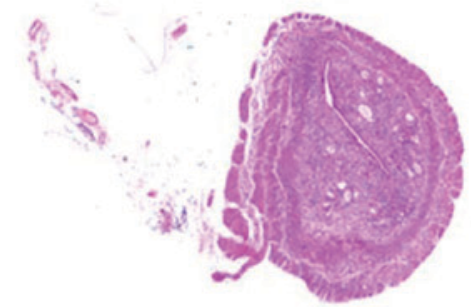

$\mathbf{F}$

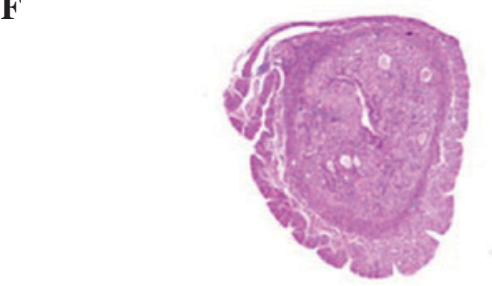

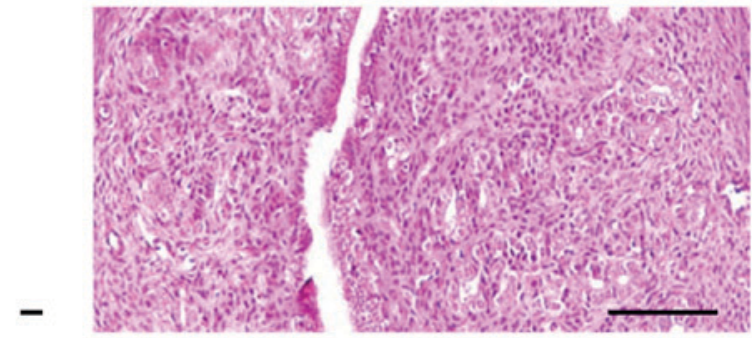
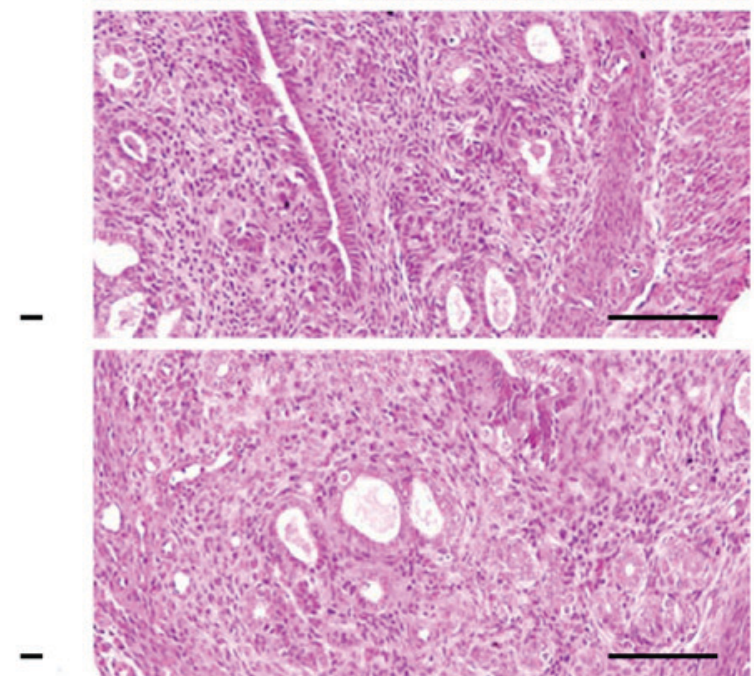

Figure 8. Representative histological images of the left uterus horn, captured from sham-operated or OVX ddY mice after hemotoxylin and eosin staining. (A) Sham-operated and distilled water-treated sham vehicle control mice; (B) distilled water-treated OVX control mice; (C) $17 \beta$-estradiol ( $0.03 \mu \mathrm{g} / \mathrm{head})$-treated OVX mice; (D) PCS (1 ml/kg)--treated OVX mice; (E) PCS (2 ml/kg)--treated OVX mice; (F) PCS (4 ml/kg)--treated OVX mice. OVX, bilateral ovariectomy; PCS, pomegranate concentrated solution, L, lumen; MU, mucosa; ML, muscular layer; UG, uterine gland. Scale bar, $120 \mu \mathrm{m}$.

histological profiles were observed in OVX control mice as significant decreases in trabecular and cortical bone masses and increases in connective tissues in periosteum of cortical bone resulting from resorption of osteoid tissues related to osteoclast activation $(\mathrm{P}<0.01)$. However, significant increases in bone mass and structures, of both trabecular and cortical bones, were detected in all test substance-administered mice including $1 \mathrm{ml} / \mathrm{kg}$ (phencyclidine) PCS-administered mice 


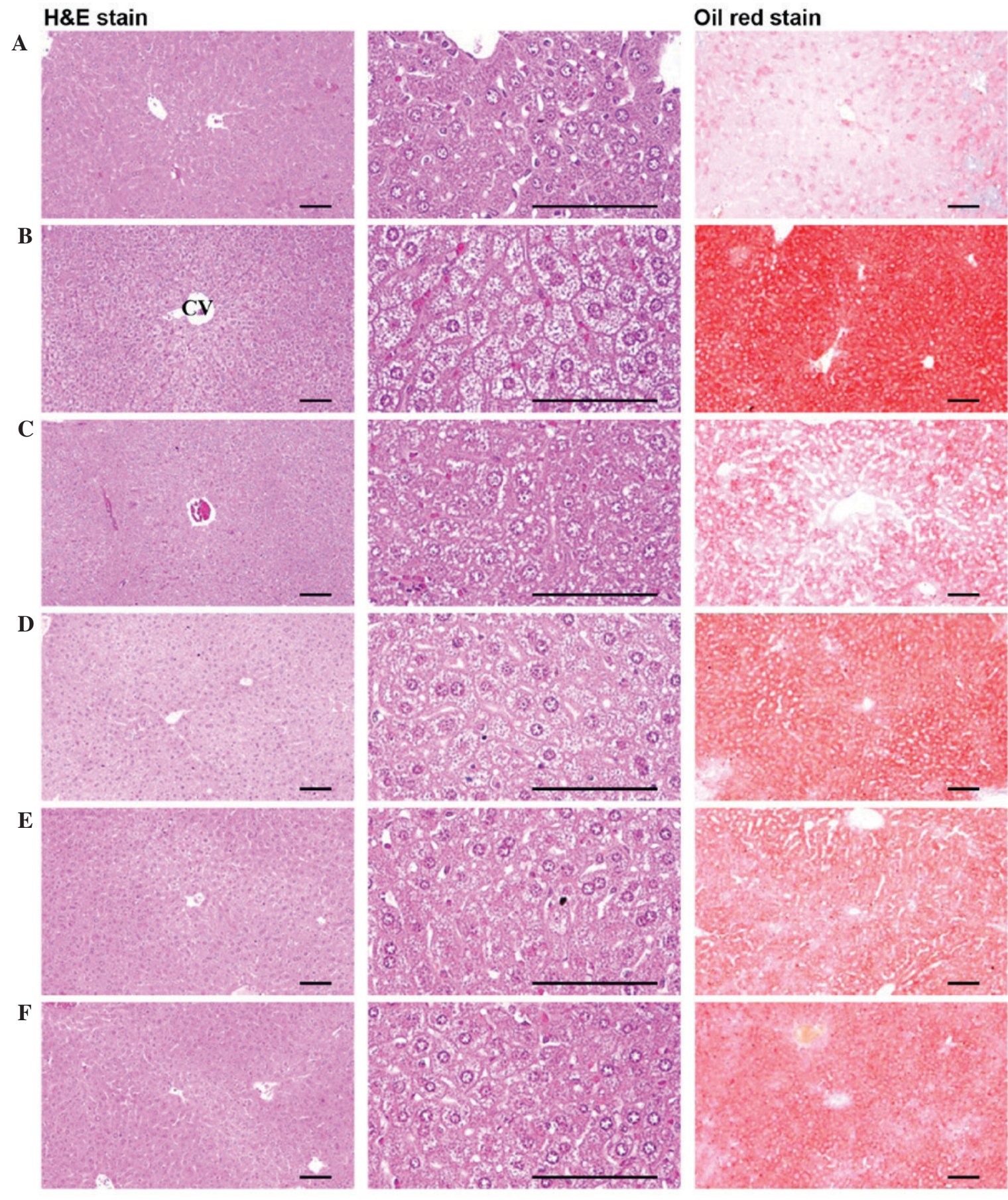

Figure 9. Representative histological images of the left lateral lobes of liver, captured from sham-operated or OVX ddY mice after hemotoxylin and eosin, and Oil Red O staining, respectively. (A) Sham-operated and distilled water-treated sham vehicle control mice; (B) distilled water-treated OVX control mice; (C) 17ß-estradiol (0.03 $\mu \mathrm{g} / \mathrm{head})$-treated OVX mice; (D) PCS (1 ml/kg)-treated OVX mice; (E) PCS (2 ml/kg)-treated OVX mice; (F) PCS (4 ml/kg)-treated OVX mice. OVX, bilateral ovariectomy; PCS, pomegranate concentrated solution, CV, central vein. Scale bar, $120 \mu \mathrm{m}$.

compared with OVX control mice, which is related to their inhibitory activities on osteoclast cell activities $(\mathrm{P}<0.05$ or $\mathrm{P}<0.01$ ) (Table VII; Fig. 10).

Significant decreases in TV/BV, Tbn, Tbt, Tbl and Cbt were detected in OVX control mice compared with sham-operated control mice in the femur $(\mathrm{P}<0.01)$. However, these decreases in bone mass and structures were significantly inhibited by treatment with estradiol and 1,2 and $4 \mathrm{ml} / \mathrm{kg}$ PCS, respectively, as compared with OVX control mice in the present study $(\mathrm{P}<0.05$ or $\mathrm{P}<0.01$ ) (Table VII; Fig. 10). Significant increases in Ocn and OS/BS were detected in OVX control mice compared with sham control mice, in the femur $(\mathrm{P}<0.01)$. However, these activations and increases in osteoclast cells were significantly inhibited by treatment with all test substances, including estradiol, as compared with OVX control mice $(\mathrm{P}<0.05$ or $\mathrm{P}<0.01)$ (Table VII; Fig. 10). These results indicated that PCS has antiosteoporosis activity.

\section{Discussion}

In the present study, PCS effectively inhibited or refined climacterium symptoms, including obesity, hyperlipidemia, hepatic 
A

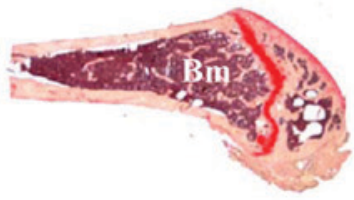

B

C
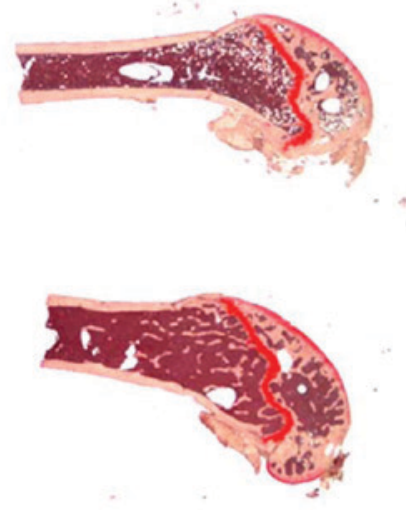

D

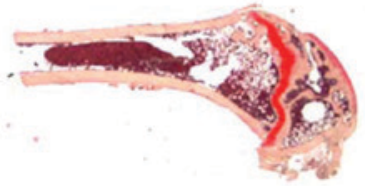

E

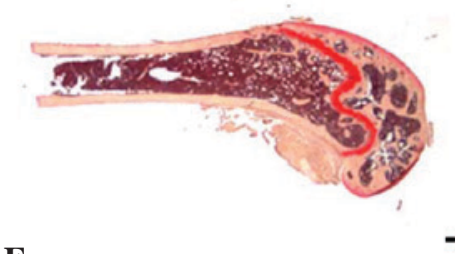

$\mathbf{F}$

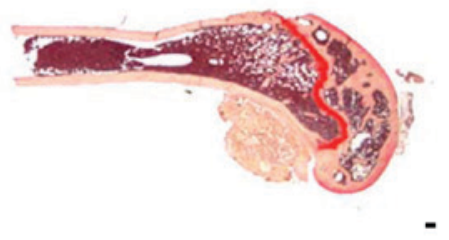

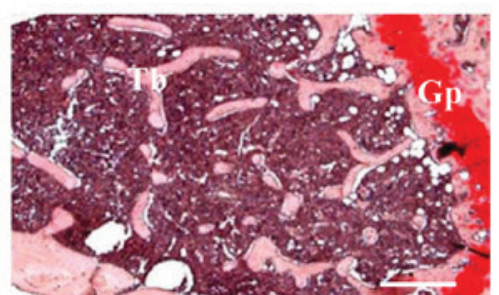
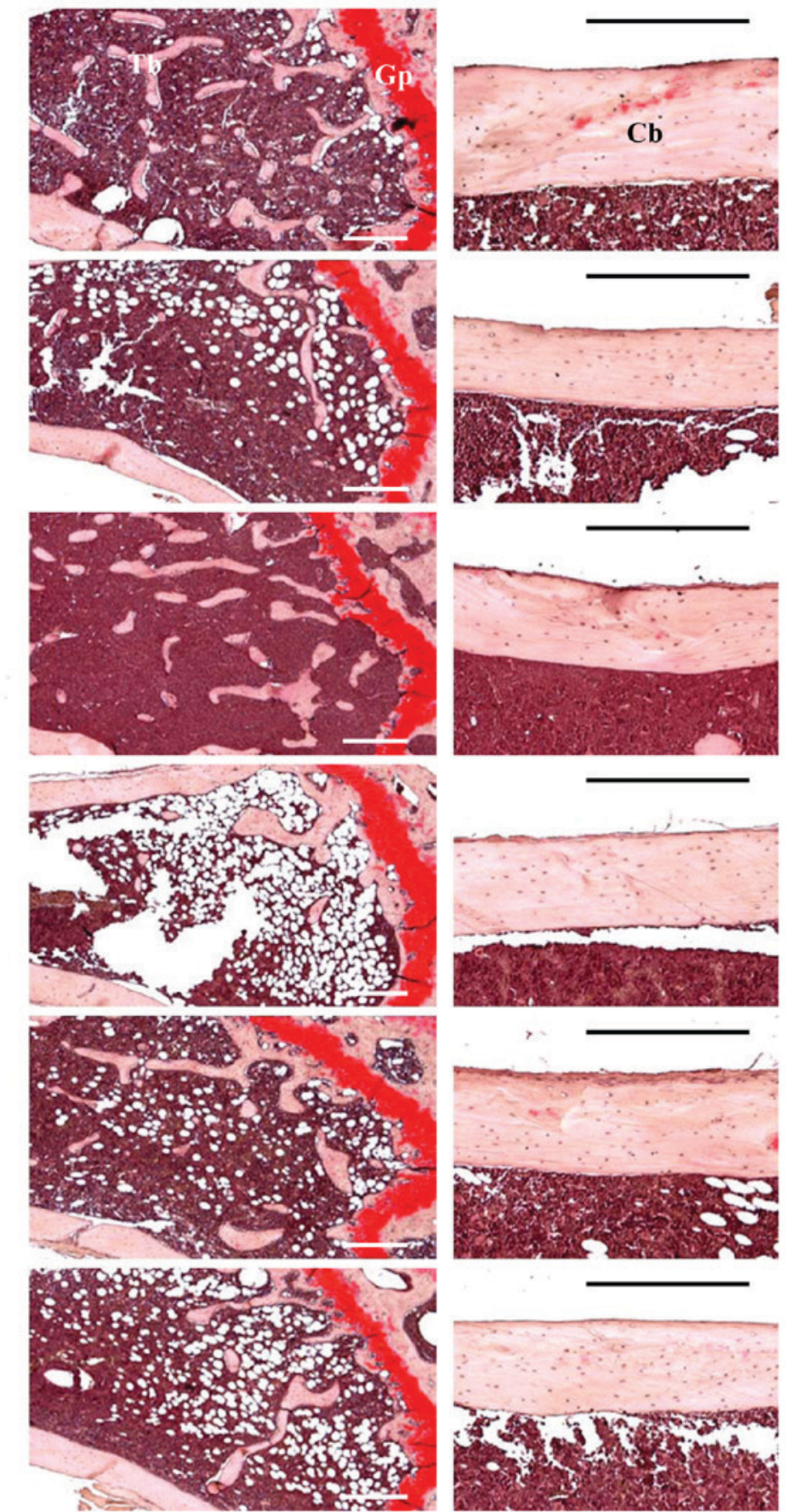

Figure 10. Representative histological profiles of the left femur, captuered from sham-operated or OVX ddY mice after Safranin O staining . (A) Sham-operated and distilled water-treated sham vehicle control mice; (B) distilled water-treated OVX control mice; (C) $17 \beta$-estradiol (0.03 $\mu \mathrm{g} /$ head)-treated OVX mice; (D) PCS (1 ml/kg)-treated OVX mice; (E) PCS (2 ml/kg)-treated OVX mice; (F) PCS (4 ml/kg)-treated OVX mice. OVX, bilateral ovariectomy; PCS, pomegranate concentrated solution, $\mathrm{Cb}$, cortical bone; $\mathrm{Tb}$, trabecular bone; Bm, bone marrow; Gp, growth plate. Scale bar, $240 \mu \mathrm{m}$.

steatosis, and osteoporosis, induced by OVX in ddY mice. The results of PCS use in the present study were consistent with the results of the use of ellagic acid and other organic materials including flavonoids and polyphenols (47-50). Previous studies have explored alternative therapies, such as the use of phytoestrogens, to relieve menopausal symptoms. Phytohormones can be extracted from plants and, when purified, exhibit enhanced activity in the body as well as improved bioavailability (18). Phytoestrogens are polyphenolic non-steroid plant compounds with estrogenic-like effects. Previous results have shown that pomegranate seed oil prevents bone loss in OVX mice through osteoblastic stimulation, osteoclastic inhibition, and decreased inflammatory status (51). In addition, pomegranate seed extract exhibits therapeutic potential for avoidance memories, which is most likely related at least in part to its phytoestrogenic and antioxidative actions $(52,53)$. The present study demonstrated that dried pomegranate concentrate powder enhanced the anti-climacteric effects of red clover in OVX rats. Therefore, we suggest that PCS is an attractive ingredient with anti-OVX benefits.

Firstly, to clarify the anti-obesity effect of PCS, food consumption, body weight and gains, and abdominal fat 


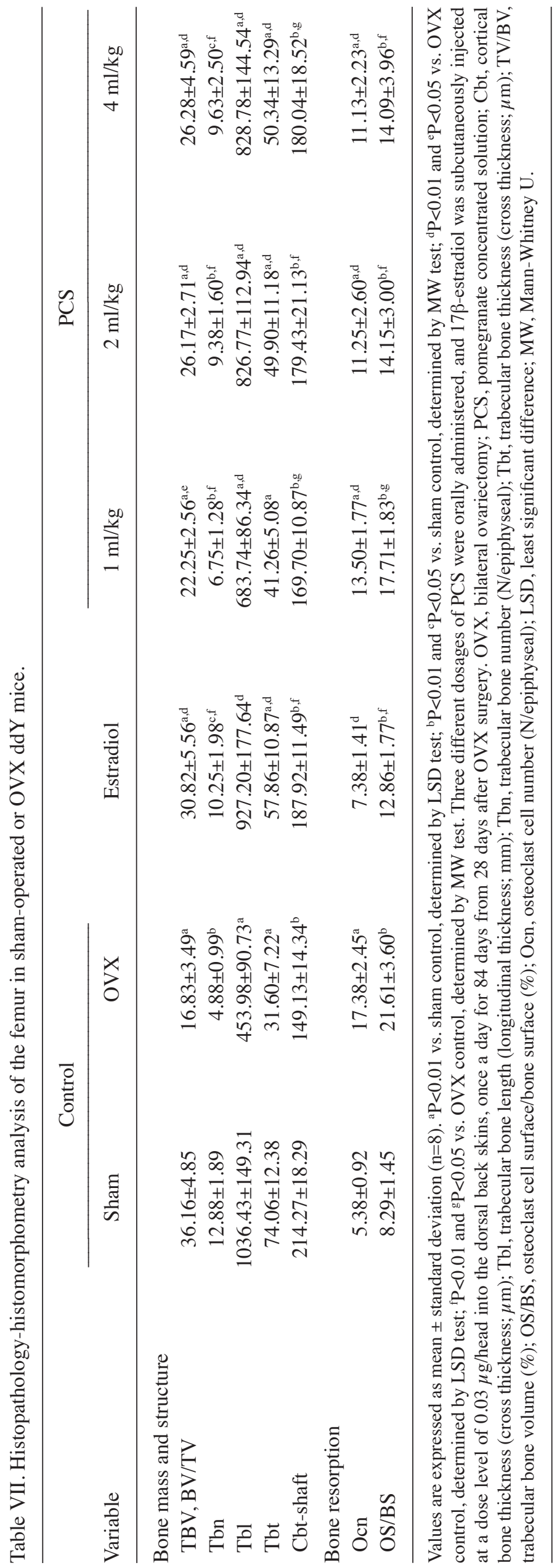


depositions were investigated. As a result, OVX-induced changes, including noticeable increases in food consumption, body weight and gains, and abdominal fat depositions with adipocyte hypertrophy, were significantly inhibited by treatment with estradiol and 1, 2, and $4 \mathrm{ml} / \mathrm{kg}$ PCS. Estrogen depletion in an OVX animal model was observed along with significant increases in food intake and changes in body fat depositions, especially in the abdominal cavity (54-56). In addition, obesity-induced OVX mice exhibited an accumulation of fat deposition and cellular hypertrophy through the expansion of intra-abdominal adipose tissue $(57,58)$. Estradiol has been shown to regulate eating and body weight by controlling the potency of the feedback signals that control meal size $(59,60)$. The correlation between cholecystokinin (CCK) and estradiol is well-documented $(61,62)$. Similar mechanisms may be in operation for glucagon as the effects of glucagon and glucagon antibodies, on decreased and increased meal size, respectively, were both enhanced by estradiol in a previous study of OVX animal models (59). In the absence of estradiol, food consumption and body weight are increased (63-65). These observations are of clinical relevance as estradiol levels decrease in postmenopausal women and, notably, postmenopausal women account for a high proportion of the obese population (55). It has been assumed that the anti-obesity effects of PCS may be mediated by estrogenic food intake effects, but more complex mechanisms are involved in the anti-obesity effects of PCS. Typically, increased digestive motility leads to stimulated fecal excretions, resulting in a reduction in body weight in rodents $(66,67)$. Diuretics are able to decrease body weight $(68,69)$ along estrogenic suppression, by enhancing the satiating potency of CCK (62) and glucagon (59). More detailed mechanistic studies are required to explore the anti-obesity effects of PCS.

Secondly, the present results showed that OVX-induced groups significantly increased serum TC, LDL and TG levels, but decreased serum HDL contents. In contrast, OVX-induced hyperlipidemia was significantly inhibited by treatment with oral 1, 2 and $4 \mathrm{ml} / \mathrm{kg}$ PCS and estradiol. This finding is similar to previous findings of a significant increase in TC, LDL, and TG, and low HDL levels, in postmenopausal women (70). Similar trends in serum lipids were observed in OVX mice (40). The effects of estradiol on serum lipid profiles are believed to be mediated by inhibiting the activity of 3-hydroxy-3-methylglutaryl coenzyme A reductase (HMG-CoA) (71). Since HMG-CoA is the rate-limiting enzyme involved in cholesterol synthesis, these effects may occur through the elevation of HMG-CoA activity, which is associated with cholesterol synthesis (71).

Thirdly, OVX-induced liver steatosis was observed in the present study, whereas 1-, 2- and 4-ml/kg PCS-treated ddY mice were significantly inhibited in OVX-induced hepatic steatosis. These findings supported the favorable hepatoprotective activity of PCS. Since the liver is the main target organ of HMG-CoA reductase $(45,72)$, hypertrophy and fatty change in hepatocytes are accompanied by increased AST and ALT activities $(73,74)$, which are related to estrogen deficiency-mediated obese and hyperlipidemia $(45,74,75)$. Estrogen deficiency is associated with an atherogenic lipid profile characterized by HDL-cholesterol, LDL-cholesterol, triglyceride levels (11), central adiposity (12), increased diastolic pressure (13), and increased insulin resistance (14).

Fourthly, the present study demonstrated, via histopathological and histomorphometrical analysis, that osteocalcin levels and bone resorption markers (Ocn and OS/BS) were significantly increased, accompanied by decreases in femur weights and serum bALP levels, in OVX control mice. In addition, bone mass and structures of the femur were decreased in OVX control mice compared with sham-operated control mice. However, these estrogen-deficient osteoporosis were effectively inhibited by 1,2 , and $4 \mathrm{ml} / \mathrm{kg}$ PCS, respectively. These results support the notion that PCS has favorable and potent anti-osteoporotic activities, as reported previously $(31,51)$. Bone loss is accelerated in menopausal women due to the loss of estrogen. Osteoporosis is a common disorder related to the imbalance between bone resorption and bone formation, which leads to bone loss and the structural deterioration of bone (76). Increased bone weight is considered a good indicator of anti-osteoporotic activities $(77,78)$, despite the fact that changes in bone weight are not an important marker for evaluating anti-osteoporotic agents, with the exception of ash bone weight (79). For an osteoporosis-related OVX model, serum bALP content and osteocalcin levels are typically accepted as bone turnover markers (80-82), and BMD is used as a major determinant of osteoporosis (83-85). As microscopic observation of bone can provide good evidence regarding bone morphology $(35,37,38,86)$, trabecular and cortical bone is significantly changed in osteoporotic animals. In addition, several histomorphometrical indices for bone mass and bone formations are clearly reduced, whereas histomorphometrical indices for bone resorption are increased $(37,38,87)$. Therefore, the histology of bones has previously been evaluated to examine the efficacy of various anti-osteoporosis agents $(37,38,86)$. In this respect, PCS exhibited anti-osteoporotic activities similar to previous findings $(31,51)$.

Lastly, OVX mice exhibited a significant decrease in uterine weights along with marked decreases in serum estradiol levels and associated uterine atrophic changes, including decreases in total, mucosa and epithelial thicknesses, and uterine glands in the mucosa. However, these estrogen-deficient uterine atrophies were significantly inhibited by PCS treatment. As estrogens are shown to act on numerous female target organs, such as the uterus, vagina, and skeletal and cardiovascular systems $(88,89)$, menopausal women may experience climacterium symptoms due to lack of estrogen $(90,91)$. Loss of estrogen is accompanied by atrophy of the uterus and vagina $(56,91)$. Phytoestrogenic effects of isoflavonoids cause increases in uterine masses via uterine water imbibitions and/or a cell proliferation $(88,92)$, which are mediated through $\mathrm{ER} \alpha(93-95)$.

In conclusion, the present results indicated that PCS effectively inhibited climacterium symptoms including obesity, hyperlipidemia, hepatic steatosis, and osteoporosis in OVX-ddY mice. Therefore, PCS may be a promising novel protective agent for relieving climacterium symptoms in menopausal women.

\section{Acknowledgements}

The present work was supported by the National Research Foundation of Korea grant funded by the Korea government 
(grant no. 2012R1A5A2A42671316) and the Basic Science Research Program provided by the Ministry of Education, Science and Technology (grant no.NRF-2012R1A1A2043886).

\section{References}

1. del Giorno C, Fonseca AM, Bagnoli VR, Assis JS, Soares JM Jr and Baracat EC: Effects of Trifolium pratense on the climacteric and sexual symptoms in postmenopause women. Rev Assoc Med Bras 56: 558-562, 2010 (In English and Portuguese).

2. Speroff L: The menopause: A signal for the future. In: Treatment of the postmenopausal woman. Lobo RA (ed) Raven Press, New York, pp1-7, 2005.

3. Wolff LP, Martins MR, Bedone AJ and Monteiro IM: Endometrial evaluation in menopausal women after six months of isoflavones. Rev Assoc Med Bras 52: 419-423, 2006 (In Protuguese).

4. Dennerstein L, Lehert P and Guthrie J: The effects of the menopausal transition and biopsychosocial factors on well-being. Arch Womens Ment Health 5: 15-22, 2002.

5. van Seumeren I: Weight gain and hormone replacement therapy: Are women's fears justified? Maturitas (34 Suppl 1): S3-S8, 2000

6. Choi JS, Koh IU and Song J: Genistein reduced insulin resistance index through modulating lipid metabolism in ovariectomized rats. Nutr Res 32: 844-855, 2012.

7. Liang YQ, Akishita M, Kim S, Ako J, Hashimoto M, Iijima K, Ohike Y, Watanabe T, Sudoh N, Toba K, et al: Estrogen receptor beta is involved in the anorectic action of estrogen. Int J Obes Relat Metab Disord 26: 1103-1109, 2002.

8. Saengsirisuwan V, Pongseeda S, Prasannarong M, Vichaiwong K and Toskulkao C: Modulation of insulin resistance in ovariectomized rats by endurance exercise training and estrogen replacement. Metabolism 58: 38-47, 2009.

9. Kannel WB, Hjortland MC, McNamara PM and Gordon T: Menopause and risk of cardiovascular disease: The Framingham study. Ann Intern Med 85: 447-452, 1976.

10. Liu Y, Ding J, Bush TL, Longenecker JC, Nieto FJ, Golden SH and Szklo M: Relative androgen excess and increased cardiovascular risk after menopause: A hypothesized relation. Am J Epidemiol 154: 489-494, 2001.

11. Warren MP and Halpert S: Hormone replacement therapy: Controversies, pros and cons. Best Pract Res Clin Endocrino Metab 18: 317-332, 2004.

12. Augoulea A, Mastorakos G, Lambrinoudaki I, Christodoulakos $\mathrm{G}$ and Creatsas G: Role of postmenopausal hormone replacement therapy on body fat gain and leptin levels. Gynecol Endocrinol 20: 227-235, 2005.

13. Reckelhoff JF: Basic research into the mechanisms responsible for postmenopausal hypertension. Int J Clin Pract Suppl 13-19, 2004.

14. Wu SI, Chou P and Tsai ST: The impact of years since menopause on the development of impaired glucose tolerance. J Clin Epidemiol 54: 117-120, 2001.

15. Han KK, Soares JM Jr, Haidar MA, de Lima GR and Baracat EC: Benefits of soy isoflavone therapeutic regimen on menopausal symptoms. Obstet Gynecol 99: 389-394, 2002.

16. Beral V, Bull D and Reeves G; Million Women Study Collaborators: Endometrial cancer and hormone-replacement therapy in the Million Women Study. Lancet 365: 1543-1551, 2005.

17. Kaari C, Haidar MA, Júnior JM, Nunes MG, Quadros LG, Kemp C, Stavale JN and Baracat EC: Randomized clinical trial comparing conjugated equine estrogens and isoflavones in postmenopausal women: A pilot study. Maturitas 53: 49-58, 2006.

18. Knight DC and Eden JA: A review of the clinical effects of phytoestrogens. Obstet Gynecol 87: 897-904, 1996.

19. Setchell KD: Phytoestrogens: The biochemistry, physiology, and implications for human health of soy isoflavones. Am J Clin Nutr 68 (6 Suppl): 1333S-1346S, 1998.

20. Bachmann GA: Vasomotor flushes in menopausal women. Am J Obstet Gynecol 180: S312-S316, 1999.

21. Hedelin M, Klint A, Chang ET, Bellocco R, Johansson JE, Andersson SO, Heinonen SM, Adlercreutz H, Adami HO, Grönberg H and Bälter KA: Dietary phytoestrogen, serum enterolactone and risk of prostate cancer: The cancer prostate Sweden study (Sweden). Cancer Causes Control 17: 169-180, 2006.

22. Taku K, Umegaki K, Sato Y, Taki Y, Endoh K and Watanabe S: Soy isoflavones lower serum total and LDL cholesterol in humans: A meta-analysis of 11 randomized controlled trials. Am J Clin Nutr 85: 1148-1156, 2007.
23. Ma DF, Qin LQ, Wang PY and Katoh R: Soy isoflavone intake increases bone mineral density in the spine of menopausal women: Meta-analysis of randomized controlled trials. Clin Nutr 27: 57-64, 2008.

24. Sreeja S, Santhosh Kumar TR, Lakshmi BS and Sreeja S: Pomegranate extract demonstrate a selective estrogen receptor modulator profile in human tumor cell lines and in vivo models of estrogen deprivation. J Nutr Biochem 23: 725-732, 2012.

25. Elfalleh W, Tlili N, Nasri N, Yahia Y, Hannachi H, Chaira N, Ying $\mathrm{M}$ and Ferchichi A: Antioxidant capacities of phenolic compounds and tocopherols from Tunisian pomegranate (Punica granatum) fruits. J Food Sci 76: C707-C713, 2011.

26. Zahin M, Aqil F and Ahmad I: Broad spectrum antimutagenic activity of antioxidant active fraction of punica granatum L. peel extracts. Mutat Res 703: 99-107, 2010.

27. Landete JM: Ellagitannins, ellagic acid and their derived metabolites: A review about source, metabolism, functions and health. Food Res Int 44: 1150-1160, 2011.

28. Wasila H, Li X, Liu L, Ahmad I and Ahmad S: Peel effects on phenolic composition, antioxidant activity, and making of pomegranate juice and wine. J Food Sci 78: C1166-C1172, 2013.

29. Lansky EP and Newman RA: Punica granatum (pomegranate) and its potential for prevention and treatment of inflammation and cancer. J Ethnopharmacol 109: 177-206, 2007.

30. Singh RP, Chidambara Murthy KN and Jayaprakasha GK: Studies on the antioxidant activity of pomegranate (Punica granatum) peel and seed extracts using in vitro models. J Agric Food Chem 50: 81-86, 2002.

31. Mori-Okamoto J, Otawara-Hamamoto Y, Yamato H and Yoshimura H: Pomegranate extract improves a depressive state and bone properties in menopausal syndrome model ovariectomized mice. J Ethnopharmacol 92: 93-101, 2004.

32. Tominaga K, Yamauchi A, Shuto H, Niizeki M, Makino K, Oishi R and Kataoka Y: Ovariectomy aggravates convulsions and hippocampal gamma-aminobutyric acid inhibition induced by cyclosporin A in rats. Eur J Pharmacol 430: 243-249, 2001.

33. Iwamoto J, Seki A, Takeda T, Sato Y, Yamada H and Yeh JK: Comparative therapeutic effects of alendronate and alfacalcidol on cancellous and cortical bone mass and mechanical properties in ovariectomized osteopenic rats. J Nutr Sci Vitaminol (Tokyo) 52: 1-8, 2006.

34. Cheng K and Tian SL: Effects of preventive-electroacupuncture of 'Guanyuan' (CV 4) and 'Sanyinjiao' (SP 6) on hypothalamus-pituitary-ovary axis in ovariectomized rats. Zhen $\mathrm{Ci}$ Yan Jiu 37: 15-19, 45, 2012 (In Chinese).

35. Yamaguchi K, Yada M, Tsuji T, Kuramoto M and Uemura D: Suppressive effect of norzoanthamine hydrochloride on experimental osteoporosis in ovariectomized mice. Biol Pharm Bull 22: 920-924, 1999.

36. Ku SK and Lee HS: Distribution and frequency of endocrine cells in the pancreas of the ddY mouse: An immunohistochemical study. Eur J Histochem 49: 125-130, 2005.

37. Han SY, Lee JR, Kwon YK, Jo MJ, Park SJ, Kim SC, Lee HS and $\mathrm{Ku}$ SK: Ostreae Testa prevent ovariectomy-induced bone loss in mice by osteoblast activations. J Ethnopharmacol 114: 400-405, 2007.

38. Shin HD, Yang KJ, Park BR, Son CW, Jang HJ and Ku SK: Antiosteoporotic effect of Polycan, beta-glucan from Aureobasidium, in ovariectomized osteoporotic mice. Nutrition 23: 853-860, 2007.

39. US Food and Drug Administration: Guidelines for preclinical and clinical evaluation of agents for the treatment or prevention of postmenopausal osteoporosis. Rockville, MA, 1994.

40. Chiba H, Uehara M, Wu J, Wang X, Masuyama R, Suzuki K, Kanazawa K and Ishimi Y: Hesperidin, a citrus flavonoid, inhibits bone loss and decreases serum and hepatic lipids in ovariectomized mice. J Nutr 133: 1892-1897, 2003.

41. Murakami A, Song M, Katsumata S, Uehara M, Suzuki K and Ohigashi H: Citrus nobiletin suppresses bone loss in ovariectomized ddY mice and collagen-induced arthritis in DBA/1J mice: Possible involvement of receptor activator of NF-kappaB ligand (RANKL)-induced osteoclastogenesis regulation. Biofactors 30: 179-192, 2007.

42. Tousen Y, Abe F, Ishida T, Uehara M and Ishimi Y: Resistant starch promotes equol production and inhibits tibial bone loss in ovariectomized mice treated with daidzein. Metabolism 60: 1425-1432, 2011.

43. Kang SJ, Lee JE, Lee EK, Jung DH, Song CH, Park SJ, Choi SH, $\mathrm{Han} \mathrm{CH}, \mathrm{Ku}$ SK and Lee YJ: Fermentation with Aquilariae Lignum enhances the anti-diabetic activity of green tea in type II diabetic db/db mouse. Nutrients 6: 3536-3571, 2014. 
44. Jung YM, Lee SH, Lee DS, You MJ, Chung IK, Cheon WH, Kwon YS, Lee YJ and Ku SK: Fermented garlic protects diabetic, obese mice when fed a high-fat diet by antioxidant effects. Nutr Res 31: 387-396, 2011

45. Lim DW, Kim JG and Kim YT: Effects of dietary isoflavones from Puerariae radix on lipid and bone metabolism in ovariectomized rats. Nutrients 5: 2734-2746, 2013.

46. Choi JS, Kim JW, Kim KY, Cho HR, Choi IS and Ku SK: Antiosteoporotic effects of Polycan in combination with calcium lactate-gluconate in ovariectomized rats. Exp Ther Med 8 957-967, 2014.

47. Kang SJ, Choi BR, Kim SH, Yi HY, Park HR, Kim DC, Choi SH, Han CH, Park SJ, et al: Dried pomegranate potentiates antiosteoporotic and anti-obesity activities of red clover dry extracts in ovariectomized rats. Nutrients 7: 2622-2647, 2015.

48. Occhiuto F, Pasquale RD, Guglielmo G, Palumbo DR, Zangla G, Samperi S, Renzo A and Circosta C: Effects of phytoestrogenic isoflavones from red clover (Trifolium pratense L.) on experimental osteoporosis. Phytother Res 21: 130-134, 2007.

49. Sung MJ, Davaatseren M, Hur HJ, Kim HJ, Ryu SY, Choi YH, Cha MR and Kwon DY: Antiosteoporotic activity of Saururus chinensis extract in ovariectomized rats. Phytother Res 26 $1182-1188,2012$

50. Kaume L, Gilbert W, Smith BJ and Devareddy L: Cyanidin 3-O-b-D-Glucoside Improves Bone Indices. J Med Food 18 690-697, 2015

51. Spilmont M, Léotoing L, Davicco MJ, Lebecque P, Mercier S, Miot-Noirault E, Pilet P, Rios L, Wittrant Y and Coxam V: Pomegranate and its derivatives can improve bone health through decreased inflammation and oxidative stress in an animal model of postmenopausal osteoporosis. Eur J Nutr 53: $1155-1164,2014$

52. Sarkaki A, Farbood Y, Hashemi S and Rafieirad M: Pomegranate seed hydroalcoholic extract improves memory deficits in ovariectomized rats with permanent cerebral hypoperfusion/ischemia. Avicenna J Phytomed 5: 43-55, 2015.

53. Sarkaki A, Rezaiei M, Gharib Naseri M and Rafieirad M: Improving active and passive avoidance memories deficits due to permanent cerebral ischemia by pomegranate seed extract in female rats. Malays J Med Sci 20: 25-34, 2013

54. Lee SH, Jin N, Paik DJ, Kim DY, Chung IM and Park Y: Consumption of legumes improves certain bone markers in ovariectomized rats. Nutr Res 31: 397-403, 2011

55. Lutz TA: Amylin may offer (more) help to treat postmenopausal obesity. Endocrinology 152: 1-3, 2011.

56. Ateba SB, Njamen D, Medjakovic S, Hobiger S, Mbanya JC, Jungbauer A and Krenn L: Eriosema laurentii De Wild (Leguminosae) methanol extract has estrogenic properties and prevents menopausal symptoms in ovariectomized Wistar rats. J Ethnopharmacol 150: 298-307, 2013

57. Morange PE, Lijnen HR, Alessi MC, Kopp F, Collen D and Juhan-Vague I: Influence of PAI-1 on adipose tissue growth and metabolic parameters in a murine model of diet-induced obesity. Arterioscler, Thromb Vasc Biol 20: 1150-1154, 2000.

58. Kim CM, Yi SJ, Cho IJ and Ku SK: Red-koji fermented red ginseng ameliorates high fat diet-induced metabolic disorders in mice. Nutrients 5: 4316-4332, 2013.

59. Geary N and Asarian L: Estradiol increases glucagon's satiating potency in ovariectomized rats. Am J Physiol Regul Integr Comp Physiol 281: R1290-R1294, 2001.

60. Asarian L and Geary N: Modulation of appetite by gonadal steroid hormones. Philos Trans R Soc Lond B Biol Sci 361: 1251-1263, 2006

61. Asarian L and Geary N: Estradiol enhances cholecystokinin-dependent lipid-induced satiation and activates estrogen receptor-alpha-expressing cells in the nucleus tractus solitarius of ovariectomized rats. Endocrinology 148: $5656-5666,2007$.

62. Thammacharoen S, Lutz TA, Geary N and Asarian L: Hindbrain administration of estradiol inhibits feeding and activates estrogen receptor-alpha-expressing cells in the nucleus tractus solitarius of ovariectomized rats. Endocrinology 149: 1609-1617, 2008

63. Eckel LA: Estradiol: A rhythmic, inhibitory, indirect control of meal size. Physiol Behav 82: 35-41, 2004

64. Geary N: The estrogenic inhibition of eating. In: Neurobiology of food and fluid intake. Stricker EM and Woods S (eds) Springer US, New York, pp307-345, 2004.

65. Butera PC: Estradiol and the control of food intake. Physiol Behav 99: 175-180, 2010
66. Bertrand RL, Senadheera S, Markus I, Liu L, Howitt L, Chen H, Murphy TV, Sandow SL and Bertrand PP: A Western diet increases serotonin availability in rat small intestine. Endocrinology 152: 36-47, 2011

67. Snedeker SM and Hay AG: Do interactions between gut ecology and environmental chemicals contribute to obesity and diabetes? Environ Health Perspect 120: 332-339, 2012.

68. Dagnault A, Deshaies Y and Richard D: Involvement of type I corticosteroid receptor in the effects of ovariectomy on energy balance. Am J Physiol 270: R199-R206, 1996.

69. Verlander JW, Tran TM, Zhang L, Kaplan MR and Hebert SC: Estradiol enhances thiazide-sensitive $\mathrm{NaCl}$ cotransporter density in the apical plasma membrane of the distal convoluted tubule in ovariectomized rats. J Clin Invest 101: 1661-1669, 1998

70. Kim HM, Park J, Ryu SY and Kim J: The effect of menopause on the metabolic syndrome among Korean women: The Korean National Health and Nutrition Examination Survey, 2001. Diabetes Care 30: 701-706, 2007.

71. Di Croce L, Bruscalupi G and Trentalance A: Independent behavior of rat liver LDL receptor and HMGCoA reductase under estrogen treatment. Biochem Biophys Res Commun 224: 345-350, 1996.

72. Wang JF, Guo YX, Niu JZ, Liu J, Wang LQ and Li PH: Effects of Radix Puerariae flavones on liver lipid metabolism in ovariectomized rats. World J Gastroenterol 10: 1967-1970, 2004.

73. Radi ZA, Koza-Taylor PH, Bell RR, Obert LA, Runnels HA, Beebe JS, Lawton MP and Sadis S: Increased serum enzyme levels associated with kupffer cell reduction with no signs of hepatic or skeletal muscle injury. Am J Pathol 179: 240-247, 2011.

74. Kanaya N, Vonderfecht S and Chen S: Androgen (dihydrotestosterone)-mediated regulation of food intake and obesity in female mice. J Steroid Biochem Mol Biol 138: 100-106, 2013.

75. Zhang L, Zhou M, Fang G, Tang Y, Chen Z and Liu X: Hypocholesterolemic effect of capsaicinoids by increased bile acids excretion in ovariectomized rats. Mol Nutr Food Res 57: 1080-1088, 2013

76. Sakai A, Nishida S, Okimoto N, Okazaki Y, Hirano T, Norimura T, Suda T and Nakamura T: Bone marrow cell development and trabecular bone dynamics after ovariectomy in ddy mice. Bone 23: 443-451, 1998.

77. Puel C, Mathey J, Kati-Coulibaly S, Davicco MJ, Lebecque P, Chanteranne B, Horcajada MN and Coxam V: Preventive effect of Abelmoschus manihot (L.) Medik. on bone loss in the ovariectomised rats. J Ethnopharmacol 99: 55-60, 2005.

78. Xie F, Wu CF, Zhang Y, Yao XS, Cheung PY, Chan AS and Wong MS: Increase in bone mass and bone strength by Sambucus williamsii HANCE in ovariectomized rats. Biol Pharm Bull 28: $1879-1885,2005$

79. Yamamoto M, Fisher JE, Gentile M, Seedor JG, Leu CT, Rodan SB and Rodan GA: The integrin ligand echistatin prevents bone loss in ovariectomized mice and rats. Endocrinology 139: 1411-1419, 1998

80. Cui Y, Bhandary B, Marahatta A, Lee GH, Li B, Kim DS, Chae SW, Kim HR and Chae HJ: Characterization of Salvia miltiorrhiza ethanol extract as an anti-osteoporotic agent. BMC Complement Altern Med 11: 120, 2011.

81. Farley JR, Chesnut CH III and Baylink DJ: Improved method for quantitative determination in serum of alkaline phosphatase of skeletal origin. Clin Chem 27: 2002-2007, 1981.

82. Li JY, Tawfeek H, Bedi B, Yang X, Adams J, Gao KY, Zayzafoon M, Weitzmann MN and Pacifici R: Ovariectomy disregulates osteoblast and osteoclast formation through the T-cell receptor CD40 ligand. Proc Natl Acad Sci USA 108: 768-773, 2011.

83. Bilston LE, Little DG, Smith NC, Williams P and Briody J: Zoledronic acid improves the mechanical properties of normal and healing bone. Clin Biomech (Bristol, Avon) 17: 716-718, 2002

84. Diez F: Guidelines for the diagnosis of osteoporosis by densitometric methods. J Manipulative Physiol Ther 25: 403-415, 2002.

85. Syed Z and Khan A: Bone densitometry: Applications and limitations. J Obstet Gynaecol Can 24: 476-484, 2002.

86. Heikkinen T, Puolivali $\mathrm{J}$ and Tanila H: Effects of long-term ovariectomy and estrogen treatment on maze learning in aged mice. Exp Gerontol 39: 1277-1283, 2004.

87. Glatt M, Pataki A, Evans GP, Hornby SB and Green JR: Loss of vertebral bone and mechanical strength in estrogen-deficient rats is prevented by long-term administration of zoledronic acid. Osteoporos Int 15: 707-715, 2004 
88. Couse JF and Korach KS: Estrogen receptor null mice: What have we learned and where will they lead us? Endocr Rev 20: 358-417, 1999.

89. Korach KS, Migliaccio S and Davis VL: Estrogens. In: Principles of Pharmacology: Basic Concepts and Clinical Applications Munson PL, Mueller RA and Breese GR (eds) Chapman \& Hall, New York, pp809-825, 1995.

90. Turner RT, Riggs BL and Spelsberg TC: Skeletal effects of estrogen. Endocr Rev 15: 275-300, 1994.

91. Versi E, Harvey MA, Cardozo L, Brincat M and Studd JW: Urogenital prolapse and atrophy at menopause: A prevalence study. Int Urogynecol J Pelvic Floor Dysfunct 12: 107-110, 2001.

92. Hewitt SC, Deroo BJ, Hansen K, Collins J, Grissom S, Afshari CA and Korach KS: Estrogen receptor-dependent genomic responses in the uterus mirror the biphasic physiological response to estrogen. Mol Endocrinol 17: 2070-2083, 2003.
93. Akiyama T, Ishida J, Nakagawa S, Ogawara H, Watanabe $\mathrm{S}$, Itoh N, Shibuya M and Fukami Y: Genistein, a specific inhibitor of tyrosine-specific protein kinases. J Biol Chem 262: 5592-5595, 1987.

94. Kuiper GG, Carlsson B, Grandien K, Enmark E, Häggblad J, Nilsson S and Gustafsson JA: Comparison of the ligand binding specificity and transcript tissue distribution of estrogen receptors alpha and beta. Endocrinology 138: 863-870, 1997.

95. Cornwell T, Cohick W and Raskin I: Dietary phytoestrogens and health. Phytochemistry 65: 995-1016, 2004. 